\title{
THE SONDALO GABBRO CONTACT AUREOLE (CAMPO UNIT, EASTERN ALPS): IMPLICATIONS FOR MID-CRUSTAL MAFIC MAGMA EMPLACEMENT
}

\author{
B. PETRI ${ }^{1}$, G. MOHN ${ }^{2}$, P. ŠTÍPSKÁ ${ }^{1,3}$, K. SCHULMANN ${ }^{1,3}$, G. MANATSCHAL ${ }^{1}$ \\ ${ }^{1}$ Ecole et Observatoire des Sciences de la Terre, Institut de Physique du Globe de \\ Strasbourg - CNRS UMR7516, Université de Strasbourg, 1 rue Blessig, \\ F-67084, Strasbourg Cedex, France \\ ${ }^{2}$ Département Géosciences et Environnement, Université de Cergy-Pontoise, 5, mail Gay \\ Lussac, Neuville-sur-Oise, 95031 Cergy-Pontoise Cedex \\ ${ }^{3}$ Center for Lithospheric Research, Czech Geological Survey, 11821 Praha 1, Czech \\ Republic
}

Author contact: $\quad$ bpetri@unistra.fr

Tel: +33386850418

Fax: +33 368850402

\section{REFERENCE}

Petri B., Mohn G., Štípská P., Manatschal G., Schulmann K., 2016. The Sondalo gabbro contact aureole (Campo unit, Eastern Alps): implications for mid-crustal mafic magma emplacement. Contributions to Mineralogy and Petrology, 171 (5), 1-21. DOI:10.1007/s00410-016-1263-7

\begin{abstract}
Contact aureoles rimming plutonic rocks are the locus of metamorphism and deformations witnessing magma emplacement mechanisms in the crust. In this study, structural and petrological observations are combined to mineral equilibria modelling to unravel the polyphase tectono-metamorphic history of the Permian Sondalo gabbro and its host rock, the Campo unit (Eastern Alps). The Campo unit consists of Grt-St-Ms-Bt$\mathrm{Pl}-\mathrm{Qtz} \pm \mathrm{Sil} \pm \mathrm{And} \pm \mathrm{Crd}$ micaschists attesting of a Carboniferous prograde $P-T$ path, reaching $6 \mathrm{kbar} / 600^{\circ} \mathrm{C}$ and subsequently $5.6 \mathrm{kbar} / 650^{\circ} \mathrm{C}$. This metamorphism is coeval with the formation of a sub-vertical NE-SW trending foliation (S1) and its overprint by a sub-vertical NW-SE trending foliation (S2). The heat brought by the Permian intrusives subsequently caused heating of the Campo unit at around 3-4 kbar $/ 540^{\circ} \mathrm{C}$ reflected by regional static crystallization of cordierite and andalusite porphyroblasts. During the intrusion of the Sondalo gabbro, thermal peak conditions are recorded by Grt-Sil-SplCrd-Ilm granulitic xenoliths at $\sim 5.5 \mathrm{kbar} / 930^{\circ} \mathrm{C}$, subsequently exhumed at $\sim 4 \mathrm{kbar}$ during the development of a new foliation (S3). This foliation is localized around the pluton and moderately dips away from the centre of the pluton. In the migmatitic contact
\end{abstract}


aureole, Grt-Sil-Bt-Pl-Qtz-Ilm and Grt-Sil-Crd-Spl-Bt-Kfs-Ilm residual rocks bear the new foliation (S3) and document a decompression from $6 \mathrm{kbar} / 750^{\circ} \mathrm{C}$ to 5 $\mathrm{kbar} / 725^{\circ} \mathrm{C}$ and from $5.2 \mathrm{kbar} / 800^{\circ} \mathrm{C}$ to reach $4.8 \mathrm{kbar} / 770^{\circ} \mathrm{C}$, respectively. The $P-T-d$ paths recorded by the host rock and the xenoliths point to a two-step magma emplacement. First the Sondalo gabbro intruded the Campo unit causing heating of the host rock without deformation at 3-4 kbar. Second, the ductile flow along the pluton margins developed a new foliation (S3) during exhumation of the pluton and its immediate contact aureole from $6 \mathrm{kbar}$ to $4 \mathrm{kbar}$. Altogether, it indicates a progressive increase of mechanical coupling between the pluton and the host rock during magma emplacement.

Keywords: Alps; Austroalpine nappes; Gabbro; Contact metamorphism; Permian; Thermodynamic modelling.

\section{INTRODUCTION}

In the continental crust, mafic magmas are preferentially emplaced in the lower and middle crust (Huppert and Sparks 1988; Voshage et al. 1990; Rudnick and Fountain 1995). The heat advected and then conducted by these exceptionally hot magmas strongly modifies the metamorphic evolution of their surroundings (Wells 1980; Harley 1989; Annen et al. 2006), eventually reaching ultra-high temperatures (Clark et al. 2011). The width, thermal evolution and peak conditions of the generated metamorphic aureole are controlled by both magma and host rock properties such as magma chemistry, host rock temperature, composition and anisotropy (Barton et al. 1991), but also by magma amount and emplacement mechanisms (Annen 2011; Floess and Baumgartner 2015).

Indeed, the aureole is the locus of metamorphism (e.g. Mitchell et al. 2014) and deformation (e.g. Paterson and Farris 2006; Festa et al. 2013) related to magma emplacement, often individualized as the thermal and the structural aureoles. Therefore, the aureoles witness the complex interactions between the magma and the host rock from the thermal (Ague and Baxter 2007; Johnson et al. 2011; Dorfler et al. 2015), the chemical (Mark1 2005; Sinigoi et al. 2011) and the mechanical point of view (Paterson et al. 1991). Understanding these interactions remains critical in assessing magma emplacement processes (Paterson and Miller 1998). This can be untied by linking the $P-$ $T$ evolution to the deformation history of the host rock, by defining the pressuretemperature-deformation $(P-T-d)$ paths. This approach has been widely applied in orogenic contexts (e.g. Zwart 1962; Skrzypek et al. 2011) and also more recently for intrusions (e.g. Aguilar et al. 2015). But such studies remain rare for mafic magma emplacement, leaving their emplacement mechanisms in the continental crust poorly constrained.

To address these questions, we focus on Western Europe where the post-Variscan Permian extension is associated with intense bimodal magmatic activity (Costa and Rey 1995; Wilson et al. 2004). Whereas the geodynamic context of this event remains poorly understood, the magmatism together with lithospheric thinning are responsible for a 
widespread HT-metamorphism especially documented in the Alps (see synthesis of Schuster and Stüwe 2008). However, field relations are frequently erased by Alpine deformations (e.g. Galli et al. 2012; Manzotti et al. 2012), preventing to understand the connection between magmatism and metamorphism. In this context, the Austroalpine domain in SE Switzerland and adjacent N Italy preserves a polyphase pre-Alpine tectonic history due to minor Alpine deformation and metamorphism (Mohn et al. 2011; Bousquet et al. 2012). This situation enables to investigate rocks and structures related to the Permian emplacement of the mid-crustal Sondalo gabbro in the Campo unit (Tribuzio et al. 1999; Braga et al. 2001).

This study constrains the $P-T-d$ evolution of the metasediments hosting the Sondalo gabbro and of the xenoliths inside the intrusion using (1) crystallizationdeformation relationships associated with (2) mineral equilibria modelling, in order to (3) finally propose a model of mafic magma emplacement in the middle crust.

\section{GEOLOGICAL SETTING}

The Austroalpine domain in SE Switzerland and N Italy (Fig. 1) consists essentially of a Late-Cretaceous nappe-stack, sampling remnants of the Adriatic passive margin formed during the Jurassic rifting of the Alpine Tethys (e.g. Trümpy 1975; Mohn et al. 2011).

Variscan amphibolite facies metamorphism is documented in Grt-Ky migmatites of the Upper Tonale unit (Ulten zone; Braga et al. 2007; Langone et al. 2011), Grt-St micaschists of the Campo, Err and Bernina units (Halmes 1991; Büchi 1994; Braga et al. 2001), and inferred in the Margna unit (Guntli and Liniger 1989). This metamorphism is coeval with calc-alkaline diorites and granodiorites emplaced in the Bernina and the Margna units at 338-324 Ma (Spillmann and Büchi 1993; Von Quadt et al. 1994).

During the Permian and after the Variscan orogeny, alkaline felsic magmatic rocks emplaced at upper crustal levels. In the Bernina unit, the Carboniferous calcalkaline suite is intruded by an alkaline syenite-granite (Spillmann and Büchi 1993) at 295-292 Ma (U-Pb on Zrn; Von Quadt et al. 1994) at $P<3 \mathrm{kbar}$ (Büchi 1987) and a granodiorite at $285 \mathrm{Ma}$ at $P<4.5 \mathrm{kbar}(\mathrm{Rb}-\mathrm{Sr}$ isochron age; Boriani et al. 1982). Both calc-alkaline and alkaline intrusive rocks and their host rocks are unconformably overlain by younger alkaline rhyolites dated at $288 \pm 7 \mathrm{Ma}$ (U-Pb on Zrn; Von Quadt et al. 1994). The Permian lower crust was intruded by magmas of tholeiitic affinity such as the Fedoz and the Braccia gabbros in the Malenco unit at 281-278 Ma (U-Pb on Zrn; Hansmann et al. 2001). The Braccia gabbro emplaced at the crust-mantle transition zone around 10 kbar (Hermann et al. 1997; Hermann et al. 2001) and is overlain by HT-MP felsic granulites with Grt-Ky bearing residual rocks equilibrated at $10 \mathrm{kbar}$ for $800-850^{\circ} \mathrm{C}$ (Hermann et al. 1997; Müntener et al. 2000).

The Campo unit consists of amphibolite-facies micaschist, paragneiss as well as minor amphibolite and calc-silicate of Ordovician protolith age (Bergomi and Boriani 2012). The unit was sporadically intruded by Permian granitoids at $P<4.5 \mathrm{kbar}$ and $c a$. 
285-259 Ma based on $\mathrm{Rb}-\mathrm{Sr}$ dating on muscovite and biotite (Del Moro and Notarpietro 1987; Gazzola et al. 2000). Tourmaline-bearing pegmatites in the Campo unit are dated at 257-250 Ma (Sm-Nd on garnet and Rb-Sr on muscovite; Bachmann and Grauert 1981; Sölva et al. 2003). $\mathrm{K}-\mathrm{Ar}$ and ${ }^{40} \mathrm{Ar} /{ }^{39} \mathrm{Ar}$ ages on biotite and muscovite from both pegmatites and metasediments are ranging between 217 and $187 \mathrm{Ma}$ (Hanson et al. 1966; Thöni 1981; Meier 2003; Mohn et al. 2012) and are related to exhumation and cooling during Jurassic rifting (Mohn et al. 2012). Eo-Alpine to Alpine deformation in the Campo unit is mostly localized at its borders (Schmid and Haas 1989; Gazzola et al. 2000) while rare trachytic dykes crosscut the Campo unit at $c a .32 \pm 1 \mathrm{Ma}$ (K-Ar on groundmass; Bianchi Potenza et al. 1985).

The Sondalo gabbroic complex is a $\sim 40 \mathrm{~km}^{2}$ mafic pluton derived from tholeiitic parental liquids (Tribuzio et al. 1999) emplaced in the Campo unit. The pluton is concentrically zoned with an Ol-gabbro core surrounded by Opx-Cpx-bearing gabbro with a dioritic to granodioritic rim of a variable thickness (Koenig 1964). The pluton incorporated during its emplacement roof pendants up to $300 \mathrm{~m}$ in thickness and $1 \mathrm{~km}$ in length. They are made of migmatites and granulites, both with commonly residual assemblages of Grt-Sil-Bt and Grt-Sil-Spl-Crd-Ilm, indicating Al-rich metapelitic protoliths. In the outermost xenoliths and in the contact aureole, migmatites still contain leucosomes. Only few studies are focused on the contact metamorphism in and around the Sondalo gabbro, giving $4-8 \mathrm{kbar} / 900^{\circ} \mathrm{C}$ for peak metamorphic conditions based on parageneses and prismatine stability (Braga et al. 2001; Braga et al. 2003). Sm-Nd mineral-isochron dating performed on troctolite and norite from the Sondalo gabbro s.l. gave $300 \pm 12$ and $280 \pm 10 \mathrm{Ma}$, respectively (Tribuzio et al. 1999). Conversely, $\mathrm{Rb}-\mathrm{Sr}$ isochron ages are $266 \pm 10$ and $269 \pm 16 \mathrm{Ma}$ (Tribuzio et al. 1999), identical to a U-Pb zircon age from a diorite (ca. 270 Ma; Bachmann and Grauert 1981).

In the Campo unit, greenschist facies deformation overprints Carboniferous and Permian amphibolite to granulite facies structures approaching the rift-related Eita shear zone, separating the Campo unit from the Grosina unit (Fig. 1; see Mohn et al. 2012). It consists of sub-horizontal recumbent open folds affecting the Campo metapelites and Permian pegmatites associated with localized shear-zones at the top of the Sondalo gabbro that transpose fabrics for several meters below the contact with the Grosina unit. Late Cretaceous Alpine thrusts are localized at the top of the Grosina unit and at the bottom of the Campo unit and consist of a few meters thick shear zone retrogressed to greenschist facies conditions. Locally, few subsequent normal faults were described such as the "Mortirolo" fault of Late-Cretaceous age (Meier 2003). Finally, Tertiary Alpine deformation was responsible for large-scale gentle folds with ENE-WSW trending fold axis (Fig. 1a), but this deformation is not pervasive enough to overprint pre-Permian to Jurassic fabrics. 


\section{STRUCTURAL EVOLUTION}

The area of interest preserving the pre-Alpine structures encompasses the Campo unit W of the Sondalo gabbro and NNW of the Grosina unit (Fig. 1a). In the description, "D" stands for a deformation event, "F" for fold, "S" for schistosity and numbering refers to the relative chronological sequence determined from field and microstructural observations on a local to regional scale. Field photographs are available as supplementary material.

\section{Regional S1 and S2 fabrics}

In the Campo unit, the oldest macroscopically visible fabric is a NE-SW trending steep S1 foliation (Fig. 1ac) preserved mainly in the north of the study area. S1 is marked by compositional layering, alternation of mica- and quartz-rich bands and by preferred orientation of muscovite and biotite in micaschists. Few folded quartz segregations within the $\mathrm{S} 1$ foliation represent pre-S1 quartz veins.

The $\mathrm{S} 1$ fabric is affected by open to isoclinal F2 folds with steeply plunging fold axes and steep NW-SE trending axial planes. The F2 folding leads to development of a S2 cleavage and in most places to almost complete transposition into a S2 foliation. Thus, the main structure in the Campo unit is the steep NW-SE trending S2 fabric (Fig. 1) is defined by: (1) compositional layering, (2) alternation of mica- and quartz-rich layers, (3) alignment of elongated quartz segregations as well as rare leucocratic layers probably representing segregated partial melt, and (4) the preferred orientation of biotite and muscovite. The S2 fabric is crosscut by undeformed to weakly deformed mid-Permian to Early-Triassic pegmatites (Sölva et al. 2003; Mohn et al. 2012).

Within the Sondalo gabbro, metapelitic septa are preferentially oriented parallel to the S2 fabric of the Campo unit (Fig. 1b). At the outcrop scale, S2 within the septa is defined by compositional layering, elongated quartz segregations, and by shape-preferred orientation of biotite and sillimanite.

\section{Magmatic foliation in the core of the pluton}

The Sondalo gabbro displays locally a magmatic foliation marked by preferred orientation of pyroxene, amphibole and plagioclase combined in places to an alternation of pyroxene- and/or amphibole-rich layers with plagioclase-rich layers. The magmatic foliation is parallel to the $\mathrm{S} 2$ foliation of both the metapelitic septa and the regional Campo unit (Fig. 1bc).

\section{Syn-intrusion S3 fabric}

In the contact aureole, the S2 planar fabric is reworked by the D3 deformation in a zone of few hundred meters and with intensity increasing towards the gabbro. In zones of weak D3 deformation, the S2 foliation is affected by plurimetric open $\mathrm{F} 3$ folds, with moderately plunging fold axes and axial planes moderately dipping away from the pluton 
center. In zones of strong D3 deformation, the F3 folds are tight to isoclinal with rare relicts of the S2 fabric. The S2 fabric is in places completely transposed into the S3 foliation parallel to the pluton margins and dipping moderately away from the centre of the pluton (Fig. 1bc). The S3 fabric is defined by a shape preferred orientation of elongated quartz segregations and leucosomes and the preferred orientation of biotite and sillimanite.

The D3 fabric is present in the few xenoliths close to the pluton boundary. It has a variable intensity from open microfolds (Fig. $2 \mathrm{k}$ ) to complete transposition of the previous foliation. In both the contact aureole and in the xenoliths, leucosome is present in inter-boudin partitions. Moreover, there is no solid-state recrystallization in the xenoliths, surrounding gabbroic and other magmatic rocks.

\section{PETROGRAPHY AND MINERAL CHEMISTRY}

Several oriented thin-sections of micaschists, metapelitic migmatites and granulites in and around the Sondalo gabbro were studied. One sample from regional Campo micaschists (BPA 099-12a), one Grt-Sil-Bt melanosome from the migmatitic contact aureole (BPA 003-11a) and one granulite from a metapelitic xenolith in the pluton (BPA 018-11a) were selected for detailed study (location in Fig. 1a). One additional Grt-Sil-Bt melanosome from the contact aureole (BPA 002-11d) is reported in supplementary material. Petrographic observations are summarized in Fig. 2 and interpreted in terms of crystallization/deformation relationships in supplementary figure. Mineral and end-member abbreviations follow IUGS recommendations (Siivola and Schmid 2007) plus Dum for dumortierite. Mineral analyses were carried out at the Faculteit der Aard- en Levenswetenschappen (Vrije Universiteit, Amsterdam) on a JEOL JXA-8800 Superprobe equipped with four WDS detectors with operating conditions of $15 \mathrm{kV}$ and $15 \mathrm{nA}$, and at the Institut für Mineralogie und Kristallchemie (Universität Stuttgart) on a Cameca SX 100 equipped with four WDS detectors with operating conditions of $15 \mathrm{kV}$ and $15 \mathrm{nA}$ decreased to $10 \mathrm{nA}$ for feldspars and micas. Compositional X-ray maps of garnet were performed at the Universität Stuttgart with analytical conditions of $10 \mathrm{~s}$ counting-time, $15 \mathrm{kV}, 60 \mathrm{nA}$ and $5 \mu \mathrm{m}$ beam-size.

Representative mineral analyses are reported in supplementary tables and garnet chemical profiles in Fig. 3. Ferric iron is estimated by charge balance. Compositional variables are defined as: $X_{\mathrm{Fe}}=\mathrm{Fe} /(\mathrm{Fe}+\mathrm{Mg}), \mathrm{Alm}=\mathrm{Fe}^{2+} /\left(\mathrm{Fe}^{2+}+\mathrm{Mg}+\mathrm{Ca}+\mathrm{Mn}\right)$, $\mathrm{Prp}=\mathrm{Mg} /\left(\mathrm{Fe}^{2+}+\mathrm{Mg}+\mathrm{Ca}+\mathrm{Mn}\right), \mathrm{Grs}=\mathrm{Ca} /\left(\mathrm{Fe}^{2+}+\mathrm{Mg}+\mathrm{Ca}+\mathrm{Mn}\right), \mathrm{Sps}=\mathrm{Mn} /\left(\mathrm{Fe}^{2+}+\mathrm{Mg}+\mathrm{Ca}+\mathrm{Mn}\right)$, $\mathrm{Ab}=\mathrm{Na} /(\mathrm{Na}+\mathrm{Ca}+\mathrm{K}), \mathrm{An}=\mathrm{Ca} /(\mathrm{Na}+\mathrm{Ca}+\mathrm{K})$ and $\mathrm{Or}=\mathrm{K} /(\mathrm{Na}+\mathrm{Ca}+\mathrm{K})$ for measured compositions; $x(\mathrm{Grt}, \mathrm{St}, \mathrm{Crd}, \mathrm{Bt})=\mathrm{Fe} /(\mathrm{Fe}+\mathrm{Mg}) \times 100, t(\mathrm{Bt})=(\mathrm{Ti}) \times 100$, $\mathrm{alm}=\mathrm{Fe}^{2+} /\left(\mathrm{Fe}^{2+}+\mathrm{Mg}+\mathrm{Ca}+\mathrm{Mn}\right) \times 100, \mathrm{prp}=\mathrm{Mg} /\left(\mathrm{Fe}^{2+}+\mathrm{Mg}+\mathrm{Ca}+\mathrm{Mn}\right) \times 100$, grs $=\mathrm{Ca} /\left(\mathrm{Fe}^{2+}+\mathrm{Mg}+\mathrm{Ca}+\mathrm{Mn}\right) \times 100, \mathrm{sps}=\mathrm{Mn} /\left(\mathrm{Fe}^{2+}+\mathrm{Mg}+\mathrm{Ca}+\mathrm{Mn}\right) \times 100$ for modelled isopleths. 


\section{Regional micaschist and paragneiss}

In micaschist and paragneiss from the Campo unit, alternation of quartz-rich and mica-rich layers defines the S1 fabric. This foliation is pervasively folded and transposed into the main S2 fabric. Quartz segregations preserve an elongation along S1 and S2. Rare Qtz-Fsp aggregates are preferentially elongated along S2 and may represent leucosomes. Micaschists contain Grt-St-Ms-Bt-Pl-Qtz \pm Sil \pm And \pm Crd whereas paragneisses contain Ms-Bt-Pl-Qtz. Muscovite, biotite and quartz-plagioclase aggregates are aligned along both S1 and S2. In micaschists, garnet (up to $1 \mathrm{~cm}$ in diameter) bears inclusions of ilmenite and quartz, oriented along S1 in the core and in some grains along S2 in the rim (Fig. 2a). In places, garnet is rimed by Sil-Bt aggregates (Fig. 2c). Poikiloblastic to porphyroblastic staurolite (up to few $\mathrm{cm}$ in length) and its IlmQtz \pm Chl \pm Tur inclusions are parallel to S2 (Fig. 2b). Sillimanite lies in the S2 foliation and is locally associated with biotite in D2 pressure shadows around garnet (Fig. 2c). Sporadic small cordierite ( $<1 \mathrm{~mm}$ in size) occurs in quartz aggregates and does not show any preferential orientation or pressure shadows. Local andalusite porphyroblasts (up to $10 \mathrm{~cm}$ in length) preserve muscovite, biotite, plagioclase, quartz and ilmenite inclusions aligned parallel to both S1 and S2 and do not present pressure shadows that is interpreted as a post-D2 growth (Fig. 2d). Occasionally, andalusite has small staurolite and prismatic sillimanite inclusions (up to $300 \mu \mathrm{m}$, Fig. 2e). Rare kyanite is described in the literature (Pace 1966) but not observed in this study. Ilmenite and tourmaline are accessory and present in both S1 and S2.

The micaschist BPA 099-12a was collected in an open F2 fold hinge and preserves a $\mathrm{S} 1$ foliation affected by $\mathrm{F} 2$ crenulation. The rock contains $\mathrm{Grt}-\mathrm{St}-\mathrm{Ms}-\mathrm{Bt}-\mathrm{Pl}-$ Qtz-Ilm with andalusite porphyroblasts. Garnet (few $\mathrm{mm}$ in diameter) is rimed by a $\sim 100$ $\mu \mathrm{m}$ thick biotite corona and contains arcuate inclusion trails of ilmenite parallel to $\mathrm{S} 1$ interpreted as syn-D1 flattening pattern. It shows an increase of almandine and pyrope, a decrease of $X_{\mathrm{Fe}}$ and spessartine associated with a constant grossular content from core $\left(\mathrm{Alm}=0.72, \operatorname{Prp}=0.05, \mathrm{Grs}=0.06, \mathrm{Sps}=0.17, X_{\mathrm{Fe}}=0.94\right)$ to inner $\operatorname{rim}(\mathrm{Alm}=0.82$, $\operatorname{Prp}=0.07, \mathrm{Grs}=0.05, \mathrm{Sps}=0.07, X_{\mathrm{Fe}}=0.93$, Fig. 3a). The $\sim 100 \mu \mathrm{m}$ outermost rim shows either a spessartine decrease associated with an almandine increase when in contact with biotite $\left(\mathrm{Alm}=0.86, \operatorname{Prp}=0.09, \mathrm{Grs}=0.02, \mathrm{Sps}=0.03, X_{\mathrm{Fe}}=0.91\right)$ or spessartine increase and almandine decrease when in contact with quartz (Alm $=0.82$, Prp $=0.09, \mathrm{Grs}=0.02, \mathrm{Sps}=0.07, X_{\mathrm{Fe}}=0.90$ ). Small yellow staurolite (up to $5 \mathrm{~mm}$ in length) lying in Ms-Bt aggregates contains rare biotite and ilmenite inclusions and shows a sharp $X_{\mathrm{Fe}}$ increase from unzoned core $\left(X_{\mathrm{Fe}}=0.86-0.88\right)$ to few $\mu \mathrm{m}$ thick rim $\left(X_{\mathrm{Fe}}=\right.$ 0.91). Muscovite ( $\mathrm{Si}=2.97-3.05$ a.p.f.u., $\mathrm{Al}=2.75-2.85$ a.p.f.u., $\mathrm{Na}=0.18-0.22$ a.p.f.u.) and biotite $\left(X_{\mathrm{Fe}}=0.58-0.63, \mathrm{Ti}=0.09-0.13\right.$ a.p.f.u. $)$ are stable in both $\mathrm{S} 1$ and $\mathrm{S} 2$ without significant compositional differences. Rare albite $(\mathrm{Ab}=0.92, \mathrm{An}=0.08, \mathrm{Or}=0.00)$ occurs in Qtz-Pl aggregates. Andalusite porphyroblasts (up to $1 \mathrm{~cm}$ in length) contain $\mathrm{Bt}-\mathrm{Ms}-\mathrm{Ilm}$ inclusion trails arranged parallel to F2 crenulations also present in the 
surrounding Ms-Bt matrix. Andalusite does not deflect the foliation and is therefore interpreted as growing after D2. Ilmenite occurs in the matrix and is included in numerous minerals. Based on these elements, the assemblage to be modelled is Grt-StMs-Bt-Pl-Qtz-Ilm.

\section{Migmatitic metapelite in contact aureole}

Metapelite from the contact aureole ranges from stromatitic metatexite to schollen diatexite with rare micaschist. In the migmatites, alternation of Grt-Sil-Bt-rich melanosome and well-segregated leucosomes made of Fsp-Qtz define both S2 and S3. The melanosome shows a shape-preferred mineral orientation whereas the leucosome is rarely foliated. The leucosome is made of Grt-Bt-Pl-Kfs-Qtz with minor sillimanite, pinitized cordierite and muscovite.

The melanosome commonly contains the assemblage Grt-Sil-Bt-Qtz with subordinate plagioclase, K-feldspar, pinitized cordierite, spinel, muscovite and ilmenite. Garnet (up to $1 \mathrm{~cm}$ in diameter) hosts inclusions of quartz and ilmenite preserving S1 orientation in the core and a rim with rounded inclusions of sillimanite, biotite and ilmenite (Fig. 2f). Fibrolitic sillimanite and biotite intergrowth lies parallel to S2, in the $\mathrm{F} 3$ hinge zone and parallel to S3. Randomly oriented prismatic sillimanite (up to $2 \mathrm{~cm}$ in length) crosscuts Sil-Bt nests. Sil-Spl-Ilm \pm Crn aggregates are rectangular, suggesting to represent pseudomorphs. They present a random shape preferred orientation and contain elongated ilmenite grains oriented at high angle with respect to S3 that are interpreted as former inclusions trails. Such relations are common for both staurolite and andalusite in the regional micaschists. However, as the chemistry of the aggregates closely approaches staurolite in terms of oxide composition, and $X_{\mathrm{Fe}}$ and $\mathrm{Zn}$ content of spinel (see below; Fig. 2gh and supplementary material), these pseudomorphs are interpreted as replacing staurolite. Andalusite polycrystalline aggregates in quartz layers in Sil-bearing rocks are interpreted as post-kinematic (Fig. 2i). Quartz aggregates have straight boundaries joining in triple-points and have locally weak undulose extinction. In places, muscovite $(<2 \mathrm{~mm}$ in size) contains oriented inclusions of fibrolitic sillimanite and is interpreted as postkinematic. Ilmenite is the only opaque mineral.

Melanosome BPA 003-11a has an assemblage of Grt-Sil-Crd-Spl-Bt-Kfs-Ilm. Kfs-Qtz layers, sillimanite and biotite show a moderate shape-preferred orientation defining a weakly developed S3 foliation. Garnet core has ilmenite and quartz inclusion trails oriented at high angle to the external S3 foliation. Compositional profile from the core $\left(\mathrm{Alm}=0.66, \operatorname{Prp}=0.13, \mathrm{Grs}=0.15, \mathrm{Sps}=0.06, X_{\mathrm{Fe}}=0.83\right)$ to the inner rim shows an increase of pyrope and decrease of spessartine and $X_{\mathrm{Fe}}(\mathrm{Alm}=0.73$, Prp $=0.21$, Grs $=$ $0.04, \mathrm{Sps}=0.02, X_{\mathrm{Fe}}=0.76$, Fig. 3b). The outermost rim is characterized by Sil-Bt $\pm \mathrm{Crn}$ inclusions, decrease of pyrope, increase of almandine and $X_{\mathrm{Fe}}(\mathrm{Alm}=0.82, \operatorname{Prp}=0.12$, $\left.\mathrm{Grs}=0.04, \mathrm{Sps}=0.02, X_{\mathrm{Fe}}=0.88\right)$. Matrix biotite $\left(X_{\mathrm{Fe}}=0.50-0.53, \mathrm{Ti}=0.08-0.13\right.$ a.p.f.u.) presents locally lamellar intergrowth with quartz. Common sillimanite aggregates with rectangular shapes hold abundant spinel and subordinate ilmenite and 
corundum (up to $300 \mu \mathrm{m}$ in diameter, Fig. $2 \mathrm{gh}$ ). Green spinel is hercynite with moderate gahnite content $\left(X_{\mathrm{Fe}}=0.83-0.85, \mathrm{Zn}=0.00-0.10\right.$ a.p.f.u. $)$. It is abundant in the sillimanite aggregates (Fig. $2 \mathrm{~h})$ and as bigger grains $(<100 \mu \mathrm{m})$ with common sillimanite inclusions. These aggregates are interpreted as pseudomorphs after staurolite (see above). Garnet, sillimanite and biotite grains present numerous crystal faces suggesting a growth in presence of granitic melt. Plagioclase is slightly zoned from core $(\mathrm{Ab}=0.67, \mathrm{An}=$ 0.33 , Or $=0.00)$ to $\operatorname{rim}(\mathrm{Ab}=0.82, \mathrm{An}=0.18$, Or $=0.00)$. Cordierite is largely pinitized and associated with K-feldspar in few leucocratic layers. Rare tiny muscovite $(<100 \mu \mathrm{m}$, $\mathrm{Si}=3.01-3.03$ a.p.f.u., $\mathrm{Al}=2.85$ a.p.f.u., $\mathrm{Na}=0.15$ a.p.f.u.) is randomly oriented in quartz aggregates. Ilmenite occurs either in the matrix or as inclusions in garnet and biotite whereas uncommon late cracks are filled with rutile. Based on petrographic relations, the assemblage to be modelled is Grt-Sil-Crd-Spl-Bt-Kfs-Ilm-Liq.

\section{Migmatitic and granulitic metapelites in xenoliths}

Metapelitic xenoliths, located in the external part of the pluton (see Fig. 1b), range from stromatitic metatexite to schollen diatexite, similar to rocks from the contact aureole. Grt-Sil-Bt melanosome is rarely associated with Grt-Kfs-Pl-Qtz leucosome; the latter is commonly mixed with mafic magmas, responsible for magma hybridization (e.g. Braga et al. 2001). Progressive disappearance of biotite balanced by an increase of cordierite and sillimanite is observed inward the pluton. As a result, granoblastic darkblue granulites form most of the xenoliths and have a Grt-Sil-Spl-Crd-Ilm assemblage with variable amount of staurolite, biotite, $\mathrm{Mg}$-chlorite and rare orthopyroxene $(\sim 100 \mu \mathrm{m}$ in size), corundum, sapphirine and prismatine. In xenoliths, compositional layering such as leucosome/melanosome alternation still preserves the S2 orientation whereas shapepreferred orientation of minerals along S2 is only well developed in melanosome. The S3 fabric is observed in few external xenoliths but the D3 deformation remains rare in granulitic xenoliths, usually restricted to F3 microfolds of Sil-Spl-Ilm aggregates (Fig. $2 \mathrm{k}$ ). In granulitic metapelites, garnet (up to $1 \mathrm{~cm}$ in diameter) commonly bears inclusions of green spinel, sillimanite, biotite and ilmenite and occasionally a core rich in quartz and ilmenite similar to the garnet core in Fig. 2f. Locally, garnet is mantled by a green to dark-green spinel rim (Fig. 2j). Spinel also occurs in the matrix with sillimanite needles as inclusions. Cordierite in centimetre-scale and isometric aggregates bears sillimanite, spinel and zircon inclusions. Euhedral yellow staurolite ( $<1 \mathrm{~mm}$ in size) occasionally with green spinel inclusions occurs in different locations: (1) in small pockets associated with biotite (Fig. 2l) and more often with pale-green chlorite; (2) in bands along the leucosome/melanosome border; (3) along cracks crosscutting cordierite; and (4) in the matrix of retrogressed xenolith still preserving corundum, garnet and rarely spinel and cordierite. Ilmenite occurs in the matrix and no rutile was observed.

The sample BPA 018-11a is a felsic granulite with the assemblage of Grt-SilCrd-Spl-Ilm. Garnet (1 cm in diameter) bears sillimanite, spinel, biotite and ilmenite inclusions and occasionally Sil-Bt composite inclusions. The compositional profile is flat 
$\left(\mathrm{Alm}=0.72, \operatorname{Prp}=0.23, \mathrm{Grs}=0.03, \mathrm{Sps}=0.01, X_{\mathrm{Fe}}=0.76\right)$ with a $1 \mathrm{~mm}$ thick rim showing pyrope decrease balanced by an almandine and $X_{\mathrm{Fe}}$ increase $(\mathrm{Alm}=0.80, \operatorname{Prp}=$ $0.16, \mathrm{Grs}=0.03, \mathrm{Sps}=0.01, X_{\mathrm{Fe}}=0.83$ ). This rim has numerous spinel inclusions. Garnet is sometimes rimed by green spinel (hercynite, $X_{\mathrm{Fe}}=0.76-0.83, \mathrm{Zn}=0.02$ a.p.f.u.) with sillimanite inclusions. Fibrolitic sillimanite occurs also in the matrix aligned along S2, along cordierite polycrystalline aggregates and is sometimes crenulated during D3 deformation (Fig. 2k). Cordierite (up to $1 \mathrm{~cm}, X_{\mathrm{Fe}}=0.37-0.40, \mathrm{Na}=0.01-0.02$ a.p.f.u., $\mathrm{K}=0.00$ a.p.f.u.) forms aggregates or individual grains, commonly includes prismatic and fibrolitic sillimanite, ilmenite and rarely zircon. Sil-Spl aggregates sometimes present $\mathrm{F} 3$ folds. Few brown-red biotite $\left(X_{\mathrm{Fe}}=0.43-0.51\right.$ and $\mathrm{Ti}=0.09-0.16$ a.p.f.u.) lies along grain boundaries, includes all matrix minerals and is therefore interpreted as retrograde. The presence of numerous crystal faces in garnet and sillimanite, and of cuspate cordierite grains in Grt-Spl aggregates indicate that granitic melt was probably present in the rock. Altogether, observations indicate that the equilibrium assemblage is Grt-Sil-Crd-Spl-Ilm-Liq.

\section{MINERAL EQUILIBRIA MODELLING}

\section{Modelling strategy}

Pseudosections were calculated using THERMOCALC 3.33 (Powell et al. 1998, 2009 version) using the dataset 5.5 (Holland and Powell 1998, November 2003 upgrade) in the system $\mathrm{MnO}-\mathrm{Na}_{2} \mathrm{O}-\mathrm{CaO}-\mathrm{K}_{2} \mathrm{O}-\mathrm{FeO}-\mathrm{MgO}-\mathrm{Al}_{2} \mathrm{O} 3-\mathrm{SiO}_{2}-\mathrm{H}_{2} \mathrm{O}-\mathrm{TiO}_{2}-\mathrm{O}_{2}$ (MnNCKFMASHTO) and assembled using the TCWizard package (Petri and Skrzypek 2013). Used $a-x$ models are after: White et al. (2005) for garnet, biotite and ilmenite; Mahar et al. (1997) and Holland and Powell (1998) for cordierite and staurolite; White et al. (2002) for orthopyroxene and spinel; Coggon and Holland (2002) for white micas; Holland and Powell (2003) for feldspar; and White et al. (2007) for silicate melt. Pseudosections were calculated using whole-rock compositions obtained by ICP-AES analyses (available as supplementary material) at Acme Laboratories (Vancouver, Canada) converted to mol. \%, corrected for the $\mathrm{CaO}$ content of apatite and reported in Figs 4-6. $\mathrm{Fe}_{2} \mathrm{O}_{3}$ content ( $\mathrm{O}$ value) was set to 0.01 to reproduce the reduced oxidation state of the pelitic rocks. Molar and compositional isopleths were plotted for selected phases of interest.

In order to closely approach the effective bulk composition, the whole rock chemistry of the two Grt-Sil-Bt melanosomes from the contact aureole (BPA 003-11a and BPA 002-11d) was corrected by fractionating the core of the porphyroblastic garnet (e.g. Spear et al. 1990). The volume and the mean chemistry of garnet core were estimated using image analysis of digitized thin-sections. Recalculated chemical compositions are presented in Fig. 5 and in the pseudosection of sample BPA 002-11d available as supplementary text and figure. 
As the four samples represent different metamorphic grades of the progressive and coherent metamorphic and structural zonation in and around the pluton, they are interpreted to record different $P-T$ stages across different levels of the Campo unit. The presence of quartz segregation lenses and absence of both leucosome and textural elements indicating the former presence of granitic melt for the micaschist sample representing the regional metamorphism (BPA 099-12a) indicates that water was present rather than granitic melt. Therefore, pseudosection is calculated with water and quartz in excess and allows constraining the prograde evolution of the regional metamorphism along which metapelites are supposed to continuously dehydrate. On the opposite, migmatites of the contact aureole and granulites underwent partial melting as indicated (1) by leucosomes associated with melanosomes, (2) by anhydrous assemblages of residual rocks indicating melt loss, and (3) other microstructural evidence, as the presence of numerous crystal faces, of cuspate grains and of rhythmic compositional zoning of some phases. Therefore granitic melt was present during metamorphism. Modelling strategy for such conditions follows the approach of White et al. (2001) and White and Powell (2002) that assumes a continuous assemblage equilibration until melt is either crystallized or becomes absent due to melt-loss (Guiraud et al. 2001; Powell et al. 2005; Štípská and Powell 2005). Consequently, only the peak and retrograde history can be constrained with a pseudosection for such samples. Accordingly, $\mathrm{H}_{2} \mathrm{O}$ content is determined using $T-M\left(\mathrm{H}_{2} \mathrm{O}\right)$ sections so that the solidus is located in the field corresponding to the observed matrix assemblage, and garnet compositional isopleths at solidus are close to peak garnet measured composition recognized by inclusions in garnet and high pyrope values (Hasalová et al. 2008).

\section{Regional metamorphism: pseudosection for micaschist sample BPA 099-12a far from the pluton}

The pseudosection for micaschist BPA 099-12a (Fig. 4) is calculated for subsolidus conditions, i.e. at $T<650^{\circ} \mathrm{C}$ with $\mathrm{H}_{2} \mathrm{O}$ and quartz in excess. Major characteristics for the pseudosection are garnet stability for $T>510^{\circ} \mathrm{C}$ and $P>3 \mathrm{kbar}$ and chlorite stable until the staurolite field ranging between $2.7 \mathrm{kbar} / 535^{\circ} \mathrm{C}$ and $8-9 \mathrm{kbar} / 670^{\circ} \mathrm{C}$. Aluminosilicate are present at $T>600-650^{\circ} \mathrm{C}$ for $P<6 \mathrm{kbar}$, plagioclase below $4-6 \mathrm{kbar}$ and cordierite below $3 \mathrm{kbar}$. Biotite is always stable. Rutile replaces ilmenite above 9 $\mathrm{kbar} / 600^{\circ} \mathrm{C}$.

Sample BPA 099-12a (Fig. 7a) with the assemblage Grt-St-Ms-Bt-Pl-Qtz-Ilm and andalusite porphyroblasts documents growth of garnet in S1 and of garnet and staurolite during S2 formation (Fig. 2ab), both in the presence of muscovite and biotite. Initiation of the prograde path is pointed by garnet core chemistry that fits with modelled isopleths around 3-4 kbar $/ 540^{\circ} \mathrm{C}$ (circle 1 in Fig. 4bc) whereas the peak pressure is reached at $6 \mathrm{kbar} / 600^{\circ} \mathrm{C}$, as indicated by the garnet inner rim chemistry (circle 2 in Fig. $4 \mathrm{abc}$ ). This path crosses the field of Grt-St-Ms-Bt-Pl-Ilm-Qtz, consistent with the assemblage in the rock. Garnet outer rim composition is inferred to reflect re- 
equilibration at peak temperature at approximately $5.6 \mathrm{kbar} / 650^{\circ} \mathrm{C}$ (circle 3 in Fig. 4bc) at conditions were staurolite was metastable. The prograde $P-T$ loop is followed by a decompression associated with cooling that may be responsible for crystallization of biotite coronas around garnet in agreement with the modal garnet isopleths (Fig. 4b). Such retrogression may also explain the slight increase of measured $X_{\mathrm{Fe}}$ in staurolite rim (circle 4 in Fig. 4e). The growth of andalusite porphyroblasts indicates that the sample reached the andalusite stability field (below $4.5 \mathrm{kbar}$ ) during the retrograde path.

\section{Contact metamorphism: pseudosection for Grt-Sil-Bt melanosome BPA 003-11a from the contact aureole}

The pseudosection for the sample BPA 003-11a (Fig. 5) was constructed with $5.66 \mathrm{H}_{2} \mathrm{O}$ mol. \%. This $\mathrm{H}_{2} \mathrm{O}$ content allows the stability field of the observed matrix assemblage Grt-Sil-Crd-Spl-Bt-Kfs-Ilm-Liq to be bounded by the solidus while satisfying the observed garnet rim chemistry. A lower $\mathrm{H}_{2} \mathrm{O}$ value shifts the solidus to higher temperature and lowers alm(Grt) that would not satisfy measured compositions. Conversely, a higher $\mathrm{H}_{2} \mathrm{O}$ content lowers the solidus temperature and garnet and spinel would not be stable together close to the liquid-in line. The major features of the pseudosection include a solidus at $T=750-850^{\circ} \mathrm{C}$ and the garnet-out line between 1 $\mathrm{kbar} / 460^{\circ} \mathrm{C}$ and $5 \mathrm{kbar} / 790^{\circ} \mathrm{C}$. Cordierite is stable below a line from $1 \mathrm{kbar} / 450^{\circ} \mathrm{C}$ to 6.5 $\mathrm{kbar} / 850^{\circ} \mathrm{C}$. At high temperature, spinel becomes stable about 1 kbar below the stability of cordierite. Biotite and K-feldspar are always stable. The ilmenite-rutile transition lies between 7 and $9 \mathrm{kbar}$. Staurolite was not found stable in the pseudosection.

In the contact aureole, the sample BPA003-11a (Fig. 7b) has the assemblage GrtSil-Crd-Spl-Bt-Kfs-Ilm. The crystallization/deformation relationships involve growth of garnet core with high grossular-values and numerous quartz and ilmenite inclusions. These features are not reproducible with the $\mathrm{H}_{2} \mathrm{O}$-undersaturated pseudosection, indicating that garnet core may have grown under a $\mathrm{H}_{2} \mathrm{O}$-saturated path occurring before melting and associated melt loss (White and Powell 2002). The sample reaches 5.2 $\mathrm{kbar} / 800^{\circ} \mathrm{C}$ where the matrix equilibrates during D3 in the Grt-Sil-Crd-Spl-Bt-KfsIlm-Liq field (circle 1 in Fig. 5bcd) and where the garnet grew while incorporating sillimanite, biotite and ilmenite (similar to Fig. 2f). Such conditions are also attested by the composition of biotite $\left(X_{\mathrm{Fe}}\right)$, spinel and the inner rim of garnet. Following their respective modal isopleths, the presence of spinel and cordierite indicates heating and/or decompression (Fig. 5ef). However, near-isobaric heating in the Sil-Crd-Spl-Bt-KfsIlm-Liq field is supported by the absence of garnet consumption in thin section (Fig. 2f) that should be associated with decompression (Fig. 5b). The relative difference in $\mathrm{Fe}-\mathrm{Mg}$ between garnet inner and outer rim is compatible with a partial re-equilibration, probably by late-diffusion close to the liquid-out line at slightly lower temperature and pressure towards $4.8 \mathrm{kbar} / 770^{\circ} \mathrm{C}$ (circle 2 in Fig. $5 \mathrm{bc}$ ). The rare occurrence of small post-S3 andalusite visible in some other samples from the same outcrop reflects the retrogression reaching andalusite stability field (Fig. 2i). 


\section{Contact metamorphism: pseudosection for granulite sample BPA 018-11a from a xenolith}

For the pseudosection of the granulite sample BPA 018-11a (Fig. 6), $\mathrm{H}_{2} \mathrm{O}$ is set to $1.96 \mathrm{~mol} \%$. Such a value allows the Grt-Sil-Crd-Spl-Ilm-Liq assemblage and the $\operatorname{alm}(\mathrm{Grt})=0.72$ to lie near the solidus. A lower value shifts the solidus to higher temperatures; alm(Grt), grs(Grt) and sps(Grt) would decrease and would not fit the measured peak garnet composition. A higher $\mathrm{H}_{2} \mathrm{O}$ content shifts both the solidus and $\mathrm{K}$ feldspar-out line to lower temperatures, but also the quartz-in line to higher pressure: modelled garnet isopleths would satisfy measured compositions only for Qtz-bearing assemblages. The pseudosection is characterized by solidus around $900^{\circ} \mathrm{C}$ for $P<6 \mathrm{kbar}$ becoming near-isobaric at $6 \mathrm{kbar}$ for $T<900^{\circ} \mathrm{C}$. Garnet-out line heads from $1 \mathrm{kbar} / 740^{\circ} \mathrm{C}$ to $6 \mathrm{kbar} / 1100^{\circ} \mathrm{C}$ and sillimanite-out line from $3.3 \mathrm{kbar} / 700^{\circ} \mathrm{C}$ to $7.8 \mathrm{kbar} / 1100^{\circ} \mathrm{C}$. Orthopyroxene is stable below $1-3 \mathrm{kbar}$ and $1000^{\circ} \mathrm{C}$ and cordierite below $\sim 8 \mathrm{kbar}$ where ilmenite/rutile transition occurs. Spinel is always stable except for $P>6.5 \mathrm{kbar}$ and $T<$ $820^{\circ} \mathrm{C}$. Plagioclase and K-feldspar have similar compositions and are stable below $6 \mathrm{kbar}$ and $1040^{\circ} \mathrm{C}$. Qtz-bearing assemblages are restricted to a $2.5 \mathrm{kbar}$ window at higher temperatures than $5.5 \mathrm{kbar} / 930^{\circ} \mathrm{C}$. Corundum and sapphirine were not found stable in the modelled pseudosection.

$P-T$ conditions for the sample BPA 018-11a are constrained to $5.5 \mathrm{kbar} / 930^{\circ} \mathrm{C}$ (circle in Figs 6bce and 10d) by the Grt-Sil-Crd-Spl-Ilm-Liq matrix assemblage and a garnet flat compositional profile (Fig. 3d) interpreted to be due to diffusional reequilibration. In the sample, the former presence of granitic melt can be inferred from microtextures. Moreover, veinlets at the limit between xenoliths and gabbroic rocks attest for melt escape that may be extremely efficient to deplete xenoliths (Johnson et al. 2010). Garnet outermost rim is partially re-equilibrated by a Fe-Mg exchange between garnet and matrix phases while $\mathrm{Ca}$ and $\mathrm{Mn}$ remain constant (Fid. 5d), probably by diffusion during cooling associated with decompression below $4.5 \mathrm{kbar}$ (Fig. 6bc). This is also pointed by spinel coronas around garnet and large cordierite aggregates (Fig. 6df). The modelled K-feldspar content remains low (around $0.01 \mathrm{~mol}$ \%), in agreement with its absence in the observed sample mineralogy. Most of the matrix minerals and inclusions of sillimanite, spinel and ilmenite in garnet do not present shape-preferred orientation or pressure shadows indicating that matrix equilibration and garnet growth occurred under static conditions. Accordingly, D3 deformation reorienting Sil-Spl grains remains weak and is limited to F3 microfolds of Sil-Spl grains (Fig. 2k). 


\section{DISCUSSION}

\section{$P-T-d$ evolution of the Campo unit}

\section{Regional evolution}

Observed phase relationships indicate that the formation of both S1 and S2 occurs during the prograde path from $3-4 \mathrm{kbar} / 540^{\circ} \mathrm{C}$ to $6 \mathrm{kbar} / 600^{\circ} \mathrm{C}$, followed by a decompression reaching $5.6 \mathrm{kbar} / 650^{\circ} \mathrm{C}$ and subsequently $P<4.5 \mathrm{kbar}$ in the andalusite stability field. Petrographic observations from other samples document the growth of sillimanite in pressure-shadows of garnet during D2 deformation (Fig. 2c) while the presence of kyanite remains unconfirmed (see e.g. Pace 1966; Bianchi Potenza et al. 1978), limiting the maximal pressure to the sillimanite stability field. Additionally, as muscovite remains usually stable and only rare leucosomes are present far from the intrusion, the maximal temperature may not exceed the muscovite-out/liquid-in line that typically lies around $650^{\circ} \mathrm{C}$ for metapelites.

The occurrence of andalusite porphyroblasts with biotite, ilmenite and small staurolite and sillimanite inclusions indicate that andalusite growth rather occurred through the prograde chlorite-free breakdown of staurolite (Rubenach and Bell 1988) than through the retrograde replacement of sillimanite by andalusite (which is unlikely to occur; Pattison and Tracy 1991). However, the presence of andalusite is not consistent with the first prograde event occurring above the aluminosilicate triple point.

Consequently, we propose that the decompression should occur before the onset of a second prograde event consisting of isobaric heating at $P \approx 4 \mathrm{kbar}$, responsible for the andalusite growth and for staurolite rim re-equilibration but limited to $T<580^{\circ} \mathrm{C}$ as no sillimanite is observed. The crystallization of large post-tectonic andalusite is in agreement with a post-Variscan heating described in many places in the Alpine realm (e.g. Brugger 1994; Schuster and Stüwe 2008).

Consequently, petrographic observations combined with isochemical phase diagrams suggest two consecutive $P-T$ loops recorded by the Campo unit (Fig. 7). The first loop is inferred from both the sample far from the pluton (Fig. 7a) and from the contact aureole (Fig. 7bc). Regional burial is synchronous to the formation of S1 and S2 regional fabric and therefore precede the early stages of magma emplacement. Based on the inferred Proterozoic to Ordovician protolith age for the metasediments (Bergomi and Boriani 2012), and the available geochronological dataset in the Campo and adjacent units (see geological setting and Thöni 1981; Langone et al. 2011), we propose that this metamorphic stage belongs to the Carboniferous Variscan orogeny, as already suggested by Hoinkes and Thöni (1993).

\section{Evolution of the contact aureole}

Samples BPA 003-11a and BPA 002-11d (see supplementary material) document a similar $P-T-d$ evolution around $5.2 \mathrm{kbar} / 800^{\circ} \mathrm{C}$ and $6 \mathrm{kbar} / 750^{\circ} \mathrm{C}$ followed by a slight 
decompression associated with cooling to reach $4.8 \mathrm{kbar} / 770^{\circ} \mathrm{C}$ and $5 \mathrm{kbar} / 725^{\circ} \mathrm{C}$, respectively, during the formation of S3. Diffusion slightly affected garnet from core to outermost rim (Florence and Spear 1991; Caddick et al. 2010) but is more visible in the outermost rim due to the presence of strong pre-diffusion chemical gradients. In sample BPA 002-11d garnet presents variations in grossular-content (see supplementary figure) probably associated with an incorporation of calcium released by the apatite consumption at the onset of partial melting (e.g. Indares et al. 2008) Samples from the contact aureole and micaschist BPA 099-12a sampled far from the pluton have garnet cores with similar compositional zoning (Fig. 3b) and inclusions indicating growth before S3 (similar to Fig. 2f). Moreover, the sample BPA003-11a from the contact aureole contained pre-S3 staurolite as pointed by the pseudomorphs of Sil-Spl-Ilm \pm Crn (Fig. 2gh). This suggests that all three samples record a similar initial prograde evolution with growth of garnet (modelled only for sample BPA 099-12a), followed by a second heating event responsible for andalusite porphyroblasts growth and migmatization (Fig. 7b), before being exhumed below $4.5 \mathrm{kbar}$. However, measured Ti-contents of biotite for all three samples are higher than the modelled values (Figs 4d, 5d and supplementary material) and not reconcilable with the observed assemblages, indicating that: (1) the biotite is not re-equilibrated along the retrograde path, and (2) the thermodynamic model of biotite still needs to be refined (e.g. White et al. 2014).

\section{Evolution of xenoliths}

The granulite BPA 018-11a sampled in a metapelitic xenolith presents a higher $T$ evolution than the other samples (Fig. 7d). Whereas it is not visible in the modelled sample, garnet in xenoliths sometimes preserves inherited cores with numerous quartz and ilmenite inclusions similar to the samples from the regional metamorphism (core of garnet in Fig. 2f) and from the contact aureole, surrounded by a sillimanite-rich garnet rim. This indicates a comparable prograde evolution between metapelites far from the pluton, in the contact aureole and in xenoliths. Consequently, the protolith of the highergrade septa is probably close to the micaschist BPA 099-12a in terms of composition, mineralogy (on the exception of syn- to post-intrusion andalusite) and structure.

Presence of staurolite in high-grade rocks such as documented in our study (Fig. 21 and supplementary material) is described to be part of the assemblage for metamorphic rocks close to the fluid-present solidus (up to $675^{\circ} \mathrm{C}$; García-Casco et al. 2003), or up to $1050^{\circ} \mathrm{C}$ if staurolite is stabilized by low $X_{\mathrm{Fe}}$ (Grevel et al. 2002; Sato et al. 2010) or high $\mathrm{Zn}$ content (e.g. Ganguly 1972). In our case, the xenolith record higher temperature than $675^{\circ} \mathrm{C}$, staurolite has low $\mathrm{Zn}$ and $\mathrm{Mg}$ contents, spinel inclusions (Fig. 21), and occurs in biotite or Mg-chlorite rich domains. Therefore, staurolite likely occurs late in the evolution. As a consequence, the St-Bt domains are interpreted as a product of retrograde reaction with melt (Ashworth 1975; Kriegsman and Hensen 1998), biotite being sometimes retrogressed into chlorite. In a similar way, biotite lamellar intergrowth with 
quartz present in some samples is interpreted as a result of retrograde reactions with melt or aqueous fluids (Waters 2001).

The retrograde path reaching andalusite stability field for the two samples from the contact aureole and the sample from a xenolith points to decompression below 4.5 kbar. In the samples from the contact aureole, it is testified by the presence of andalusite growing statically after the end of D3 deformation (Fig. 2i). Importantly, this D3 seems to be restricted to supra-solidus conditions, as quartz presents no evidence of subsolidus deformations (e.g. grain boundary migration).

\section{Model of mafic magma emplacement in the middle crust}

Two successive $P-T$ prograde paths are recorded in the Campo unit. The second path is related to the intrusion of the Sondalo gabbro at 300-280 Ma (Tribuzio et al. 1999), and associated with HT metamorphism in the contact aureole and in metapelitic xenoliths before and during D3. A 2 kbar pressure difference occurs between samples far from the pluton (Fig. 7a) and samples in the pluton (Fig. 7bcd) at the initiation of the near-isobaric heating path, after the Variscan $P-T$ loop. This difference can be explained in two different ways.

In the first scenario, the heat brought by the intrusion is progressively transferred to the host rock (e.g. by diffusion) during the exhumation of the Campo unit. The Sondalo gabbro emplaced while the Campo unit is lying at ca. 20-21 km depth, as the samples from the resulting contact aureole document 5.5-6kbar during thermal peakconditions (Fig. 7bcd). Heat is then diffused and conducted through the synchronously exhumed Campo unit, causing a decreasing pressure at thermal peak when going away from the intrusion (reaching $P \approx 4 \mathrm{kbar}, c a .14 \mathrm{~km}$, Fig. 7a). However, this scenario can be disputed as (1) it does not explain the formation of the vertical S3 fabric in the contact aureole, and (2) if the Campo unit was heated while being tectonically exhumed, andalusite porphyroblasts growth would have been preferentially oriented. Moreover (3), the thermal peak (and therefore the end of the prograde path) at the distance of the modelled sample far from the intrusion should have been reached $c a$. $2 \mathrm{Ma}$ after magma emplacement (assuming heat transferred only by diffusion). Therefore the Campo unit should have been exhumed at a rate of $c a .4 \mathrm{~km} / \mathrm{Ma}$, which is notably higher than expected for ductile rocks (Ring et al. 1999).

We consequently favour a second scenario that integrates the observed structural evolution and where the prograde metamorphism is synchronous through the Campo unit. In this scenario, the Campo unit is already lying at $P \approx 4 \mathrm{kbar}$ at the initiation of the hightemperature prograde path. The development of pre-S3 static metamorphism in shallow levels (BPA 099-12a, labelled "a" on Fig. 8) is probably caused by the mafic magma emplacement at $\sim 20-21 \mathrm{~km}$ ( $\sim 6 \mathrm{kbar}$ ) with few shallower magmatic bodies represented by the Sondalo gabbro and the other Permian intrusives in the Campo unit (Fig. 8a). During this stage, the gabbro incorporated numerous septa remaining parallel to the general S2 fabric of the host rock (Figs $1 \mathrm{~b}$ and 8a), and recording granulite-facies 
metamorphism (BPA 018-11a, labelled "d" on Fig. 8; Braga et al. 2001; Braga et al. 2003). Xenoliths recording slightly higher pressure (Braga et al. 2003) were eventually sampled by the magma in deeper crustal levels. The similarity of $P-T$ conditions recorded by the xenolith and the host rock associated with the absence of deformation gradients at this stage may favour a hypothesis of passive magma emplacement such as the hydraulic dyking or magmatic stoping (e.g. Lister and Kerr 1991; Clemens and Mawer 1992). However, the stoping mechanism is challenged because (1) it is disabled due to host rock ductility in mid-crustal conditions (see e.g. Paterson et al. 1991; Paterson and Vernon 1995), and (2) it remains a local process allowing magma to rise over few hundred meters but not over large crustal portions (Glazner and Bartley 2006). Consequently, the magma is likely emplaced through dyking during the first stage of intrusion.

This dyking is followed by an en masse magma rise where deep xenoliths equilibrated at $\sim 20-21 \mathrm{~km}$ ( $\sim 6 \mathrm{kbar}$ ) are exhumed to $\sim 14 \mathrm{~km}$ ( $4 \mathrm{kbar})$ during D3 shearing along the margin of the pluton (Figs $7 \mathrm{~d}$ and $8 \mathrm{bc}$ ). During this exhumation (Fig. $8 b$ ), samples from the contact aureole are also exhumed and follow a similar evolution in pressure than xenoliths, suffering however lower temperature. Whereas these $T-$ variations essentially rely on the distance with respect to the pluton, $P$-variations may be generated by two mechanisms: (1) lithostatic pressure variations, therefore recording true vertical motion in the crust; or (2) by deviation from lithostatic pressure (e.g. Mancktelow 2008) due e.g. to magma overpressure. However, differential vertical motions around plutons are extensively reported in the literature (see e.g. Paterson and Vernon 1995) and are therefore favoured in this scenario. Accordingly, samples from xenoliths and the contact aureole, having a similar $P-T$ evolution, are exhumed (BPA 003-11a and BPA 002-11d, labelled "b" and "c", and BPA 018-11a on Fig. 8). Finally, all studied samples coming from the pluton interior (xenoliths) and the contact aureole are exhumed at $\sim 14 \mathrm{~km}$ ( $\sim 4 \mathrm{kbar}$, Fig. $8 \mathrm{c})$. In contrast to the previous phase, the final magma emplacement is related to material transport along the pluton margins, suggesting an active magma emplacement similar to diapiric rise of material (Ramberg 1981; Paterson et al. 1991; Warren and Ellis 1996). The shift from hydraulic diking to diapir-like emplacement of magma suggests an increasing mechanical coupling between the pluton and the host rock. This implies a progressive decrease of rheological contrast between the host rock, the contact aureole and the pluton itself due to (1) heating and partial melting of the contact aureole that drastically reduce the viscosity of the host metasediments (Arzi 1978) while (2) the viscosity of the mafic magma is lowered during its cooling. Both phenomena are subsequently followed by a general cooling of the apparatus causing an increase of the viscosity for the host rockand the mafic magma.

\section{CONCLUSION}

The study of the regional metamorphism and the contact aureole of the Sondalo gabbro emplaced in a mid-crustal position allowed to constrain a polyphase $P-T-d$ 
evolution before and during magma emplacement. Based on these results, the following conclusions are drawn:

- During the Carboniferous, the Campo unit records a period of crustal thickening associated with the D1 and D2 deformation stages, reaching 6 $\mathrm{kbar} / 600^{\circ} \mathrm{C}$ at peak- $P$ and subsequently $5.6 \mathrm{kbar} / 650^{\circ} \mathrm{C}$ at peak- $T$, before its exhumation;

- The mid-crustal Sondalo gabbro intrusion is responsible for focused host rock partial melting localized in the contact aureole and granulite facies metamorphism of metapelitic xenoliths inside the pluton;

- The heat brought by this magmatic event causes regional metamorphism as attested by cordierite and andalusite porphyroblasts static crystallization;

- $\quad P-T$ paths of migmatites from the contact aureole indicate that the emplacement of the gabbro occurred in two steps. First the gabbro intruded the Campo unit causing heating of the host rock without deformation. Second the ductile flow along the pluton margins developed S3 during the exhumation of the pluton and its immediate contact aureole from $6 \mathrm{kbar}$ to $4 \mathrm{kbar}$. This process documents a progressive increase of mechanical coupling between the pluton and the host rock during magma emplacement.

\section{ACKNOWLEDGMENTS}

We acknowledge J.C. Corona, T. Theye and G. Morvan for guidance on microprobe from Amsterdam, Stuttgart and Strasbourg, respectively. E. Skrzypek and R.F. Weinberg are thanked for informal comments and discussions, R. White and R. Braga for comments on the initial version of the manuscript. The article benefited from reviews from B. Cesare, an anonymous reviewer and from O. Müntener as editor. 


\section{FIGURE CAPTIONS}

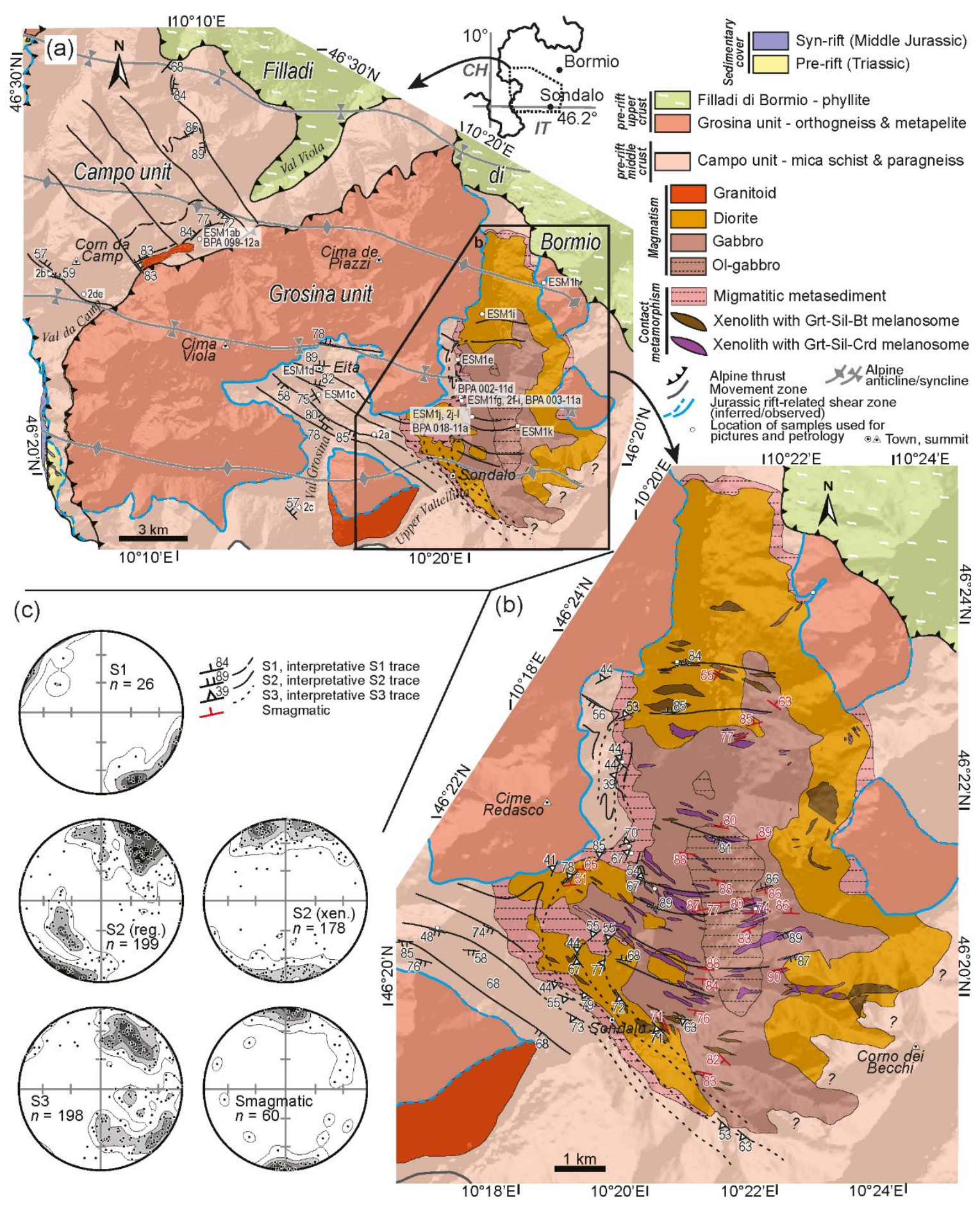

Fig. 1 Geological and structural maps of the study area. (a) The Campo and Grosina units. Location of field photographs (available as supplementary material), photomicrographs (Fig. 2) and samples used for petrology (labelled BPA) are indicated. (b) The Sondalo gabbro. Maps are compilation of Koenig (1964), Campa et al. (1997), Braga et al. (2003), Mohn et al. (2011), 1:10,000 geological maps of Italy and personal 
observations. (c) Stereonets of S1 and S2 planar structures from the host rock and S3 and magmatic foliation from the Sondalo gabbro and associated xenoliths (equal-area, lower hemisphere projection)
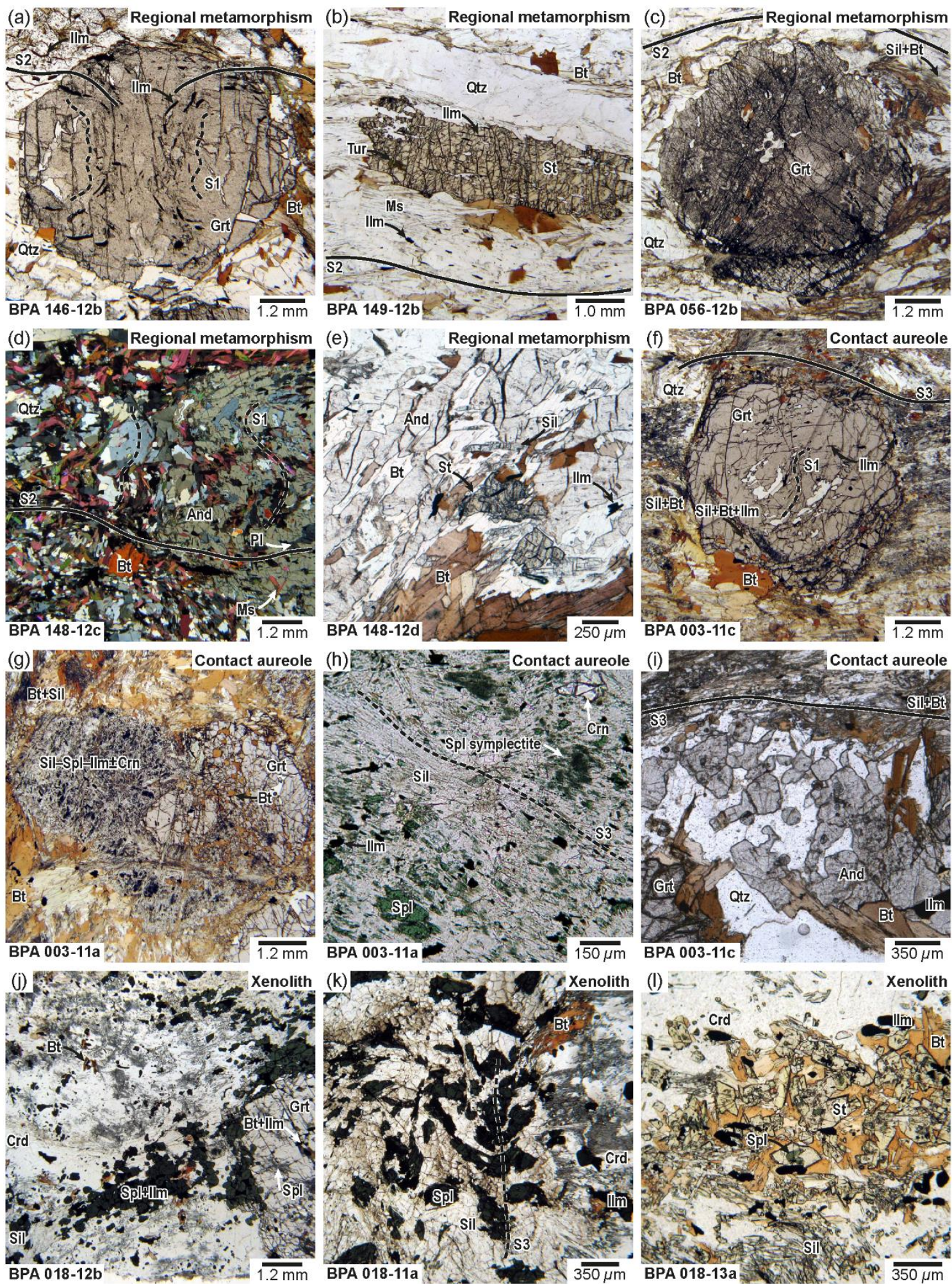
Fig. 2 Photomicrographs showing the paragenetic relationships in metapelites. Regional metamorphism: (a) garnet porphyroblast with Ilm-Qtz inclusions aligned along S1 and S2 with a millipede microstructure; (b) staurolite porphyroblast with ilmenite inclusion trails parallel to the S2 foliation; (c) Sil-Bt nests in S2 pressure shadows around garnet; (d) muscovite and biotite aligned in both S1 and S2 in the matrix and included in post-kinematic andalusite; (e) biotite, staurolite and sillimanite inclusions in postkinematic andalusite. Contact aureole: (f) garnet with Ilm-Qtz inclusions in the core and Sil-Bt-Ilm inclusions in the rim, sillimanite and biotite from the matrix are aligned along S3; (g) garnet around Sil-Spl-Ilm \pm Crn nest interpreted as a pseudomorph after andalusite, corundum in matrix surrounded by sillimanite; (h) detail of Sil-Spl-Ilm \pm Crn nest; (i) andalusite in a quartz aggregate. Metapelitic xenoliths: (j) felsic granulite with cordierite aggregates and garnet partly surrounded by spinel; (k) Sil-Spl aggregates in F3 open microfolds; (1) felsic granulite has aggregates of biotite and euhedral staurolite with spinel inclusions 
(a) Regional metamorphism - micaschist BPA 099-12a

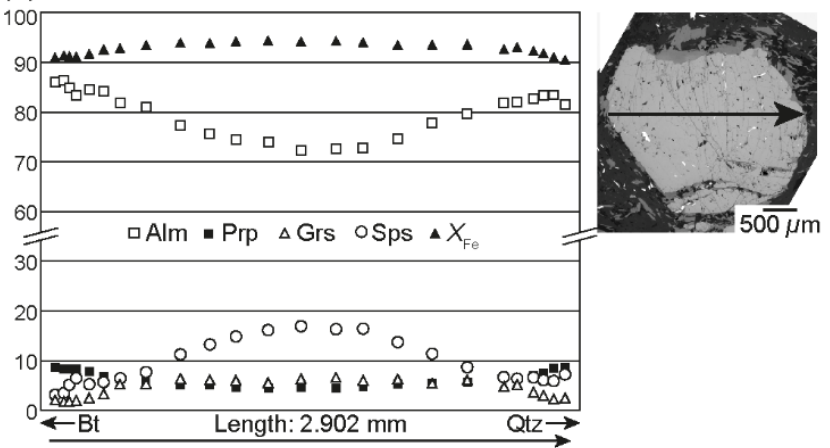

(b) Contact aureole - Grt-Sil-Bt melanosome BPA 003-11a

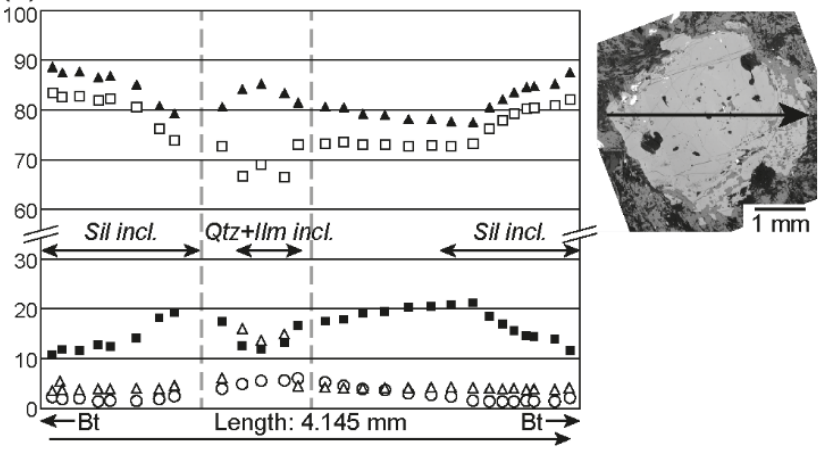

(C) Xenolith - granulite BPA 018-11a

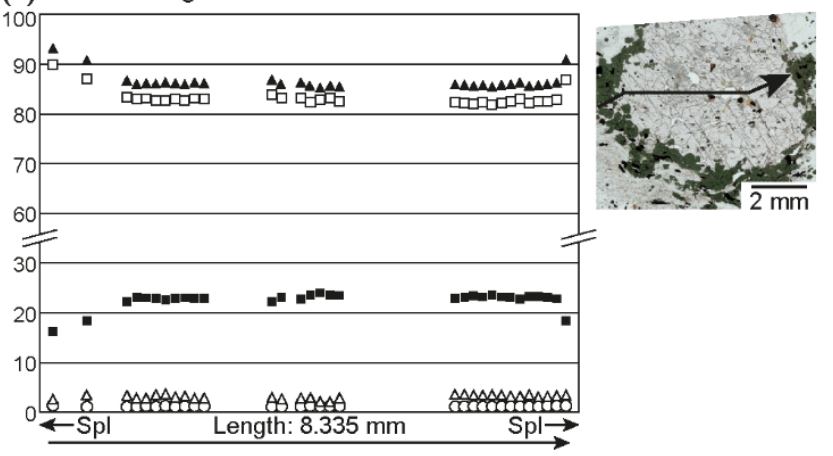

Fig. 3 Garnet compositional profiles for the samples from (a) micaschist from regional metamorphism, (b) Grt-Sil-Bt melanosome from the contact aureole and (c) granulitic xenolith 


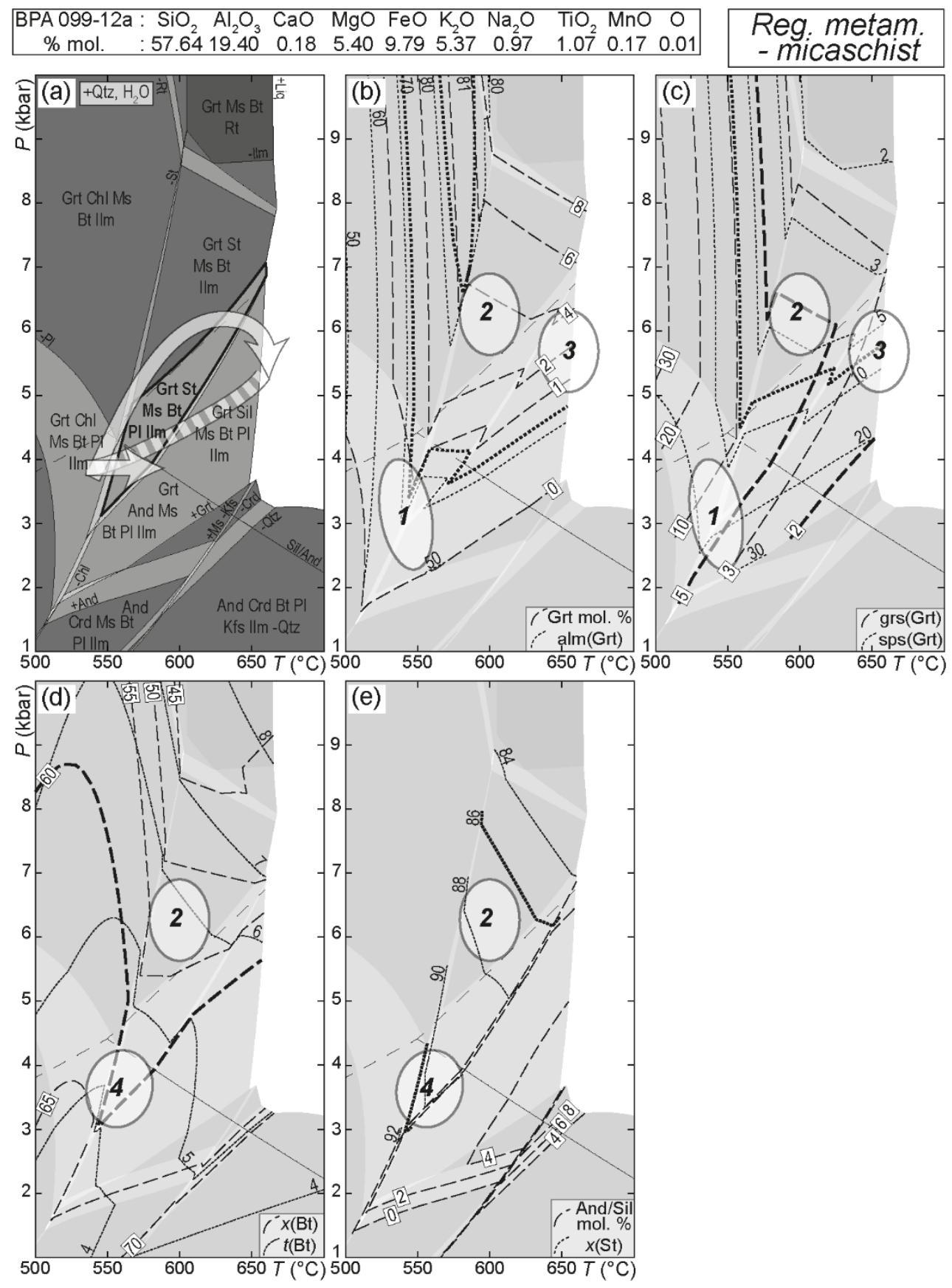

Fig. 4 (a) $P-T$ pseudosection for micaschist sample BPA 099-12a from the regional metamorphism (whole rock composition in mol. \% normalized to $100 \%$ ). See text for details. (b-e) Simplified pseudosection contoured with garnet molar and compositional isopleths and biotite and staurolite compositional isopleths. Matrix assemblage and isopleths of interest are highlighted in bold (see text for details). Ellipses indicate probable equilibration of garnet (from core to rim circles 1, 2 and 3), staurolite (circle 2 for core and circle 4 for rim) and biotite (circle 2) 


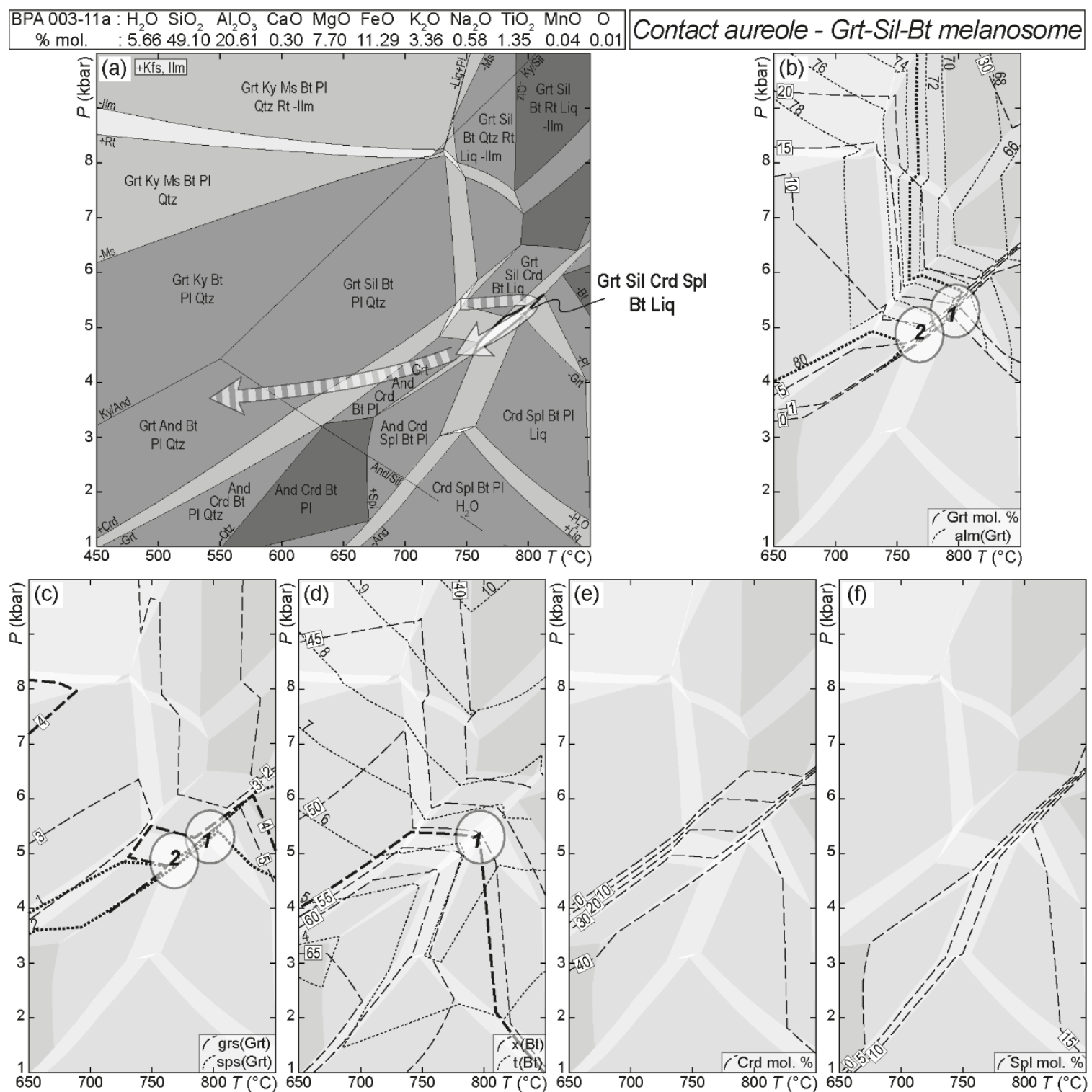

Fig. 5 (a) $P-T$ pseudosection for Grt-Sil-Bt melanosome BPA 003-11a from the contact aureole (whole rock composition in mol. \% normalized to $100 \%$ ). See text for details. (b-f) Simplified part of the pseudosection contoured with garnet molar and compositional isopleths, biotite compositional isopleths and cordierite and spinel molar isopleths. Matrix assemblage and isopleths of interest are highlighted in bold (see text for details). Ellipses indicate probable equilibration of garnet (from core to rim circles 1 for inner rim and 2 outermost rim) and biotite (circle 2) with the matrix 


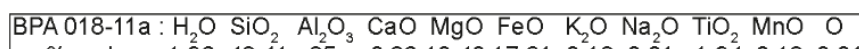

$\begin{array}{llllllllllll}\% \text { mol. } & : 1.96 & 42.41 & 25 & 0.23 & 10.40 & 17.81 & 0.12 & 0.01 & 1.94 & 0.12 & 0.01\end{array}$
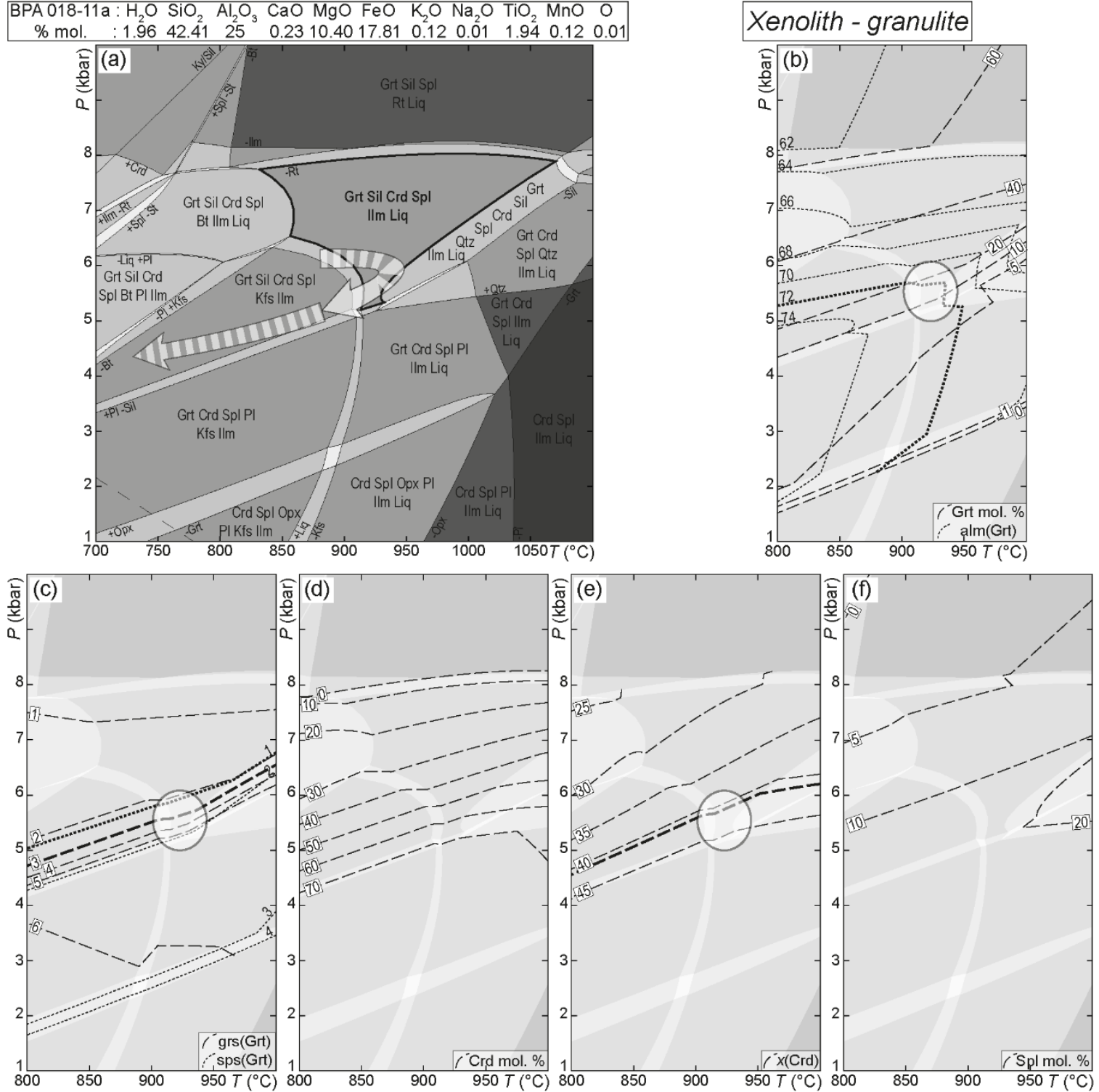

Fig. 6 (a) $P-T$ pseudosection for granulite sample BPA 018-11a from a

metapelitic xenolith (whole rock composition in mol. \% normalized to 100\%). See text for details. (b-f) Simplified part of the pseudosection contoured with garnet molar and compositional isopleths, cordierite molar and compositional isopleths and spinel molar isopleths. Matrix assemblage and isopleths of interest are highlighted in bold (see text for details). Ellipse indicates probable equilibration of garnet core and cordierite with the matrix 
(a) Regional metamorphism - micaschist BPA 099-12a

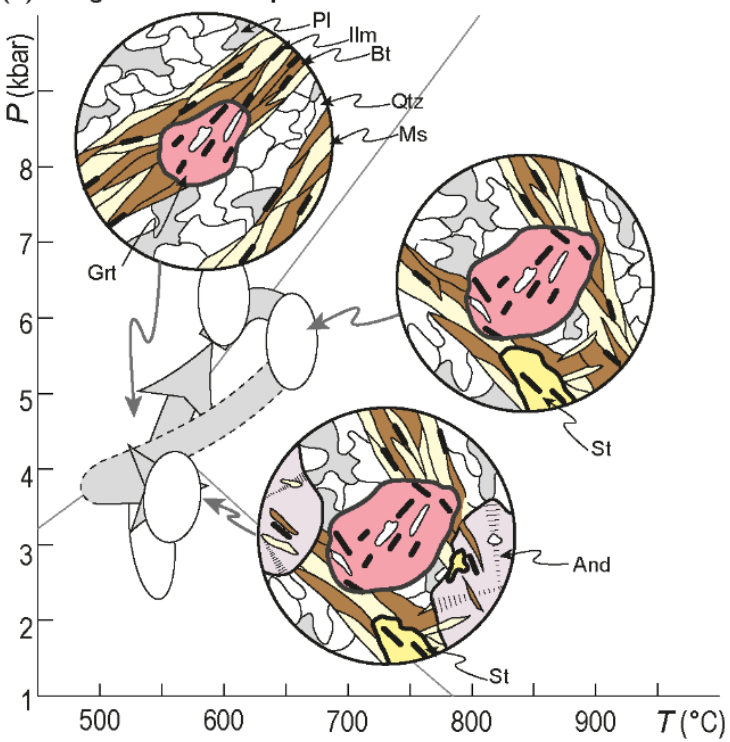

(c) Contact aureole - Grt-Sil-Bt melanosome BPA 002-11d

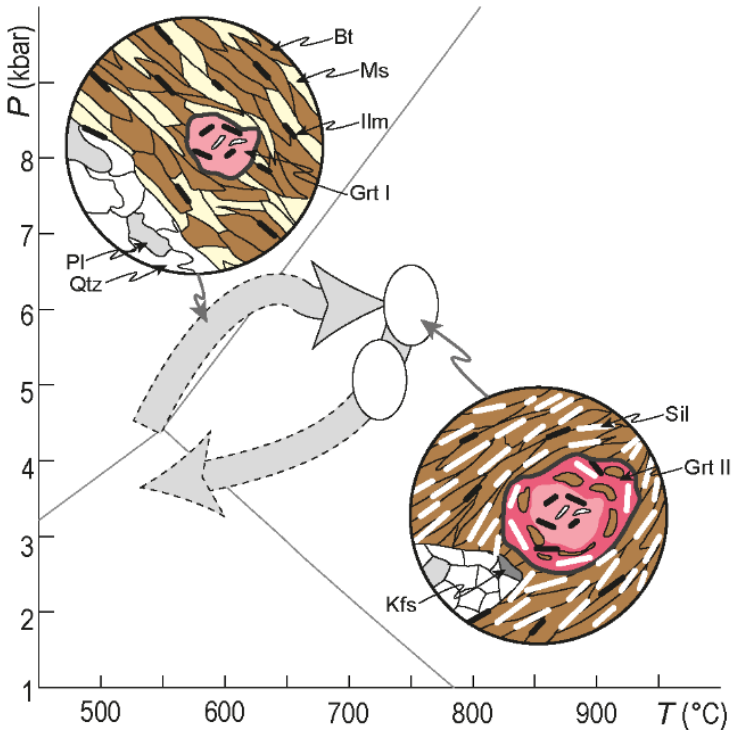

(b) Contact aureole - Grt-Sil-Bt melanosome BPA 003-11a

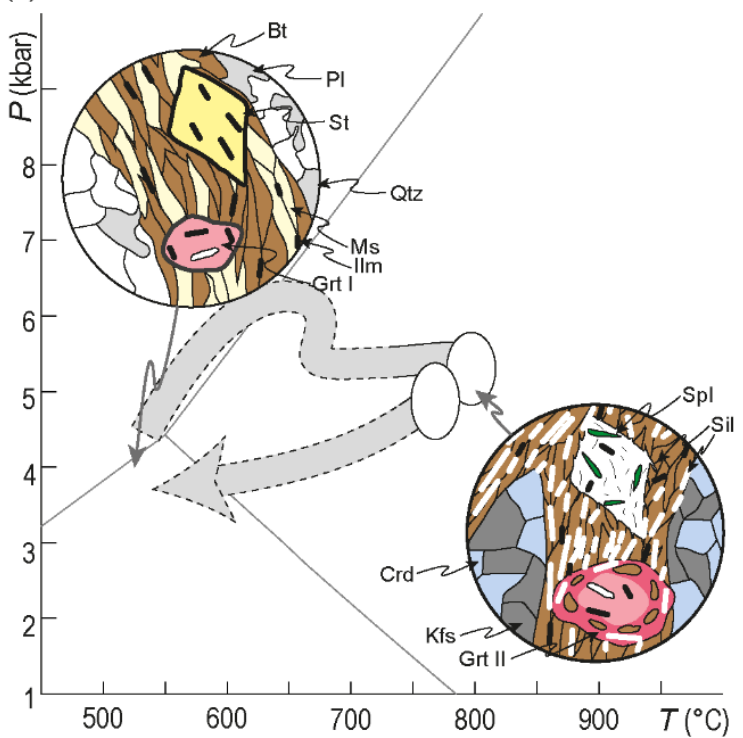

(d) Xenolith - granulite BPA 018-11a

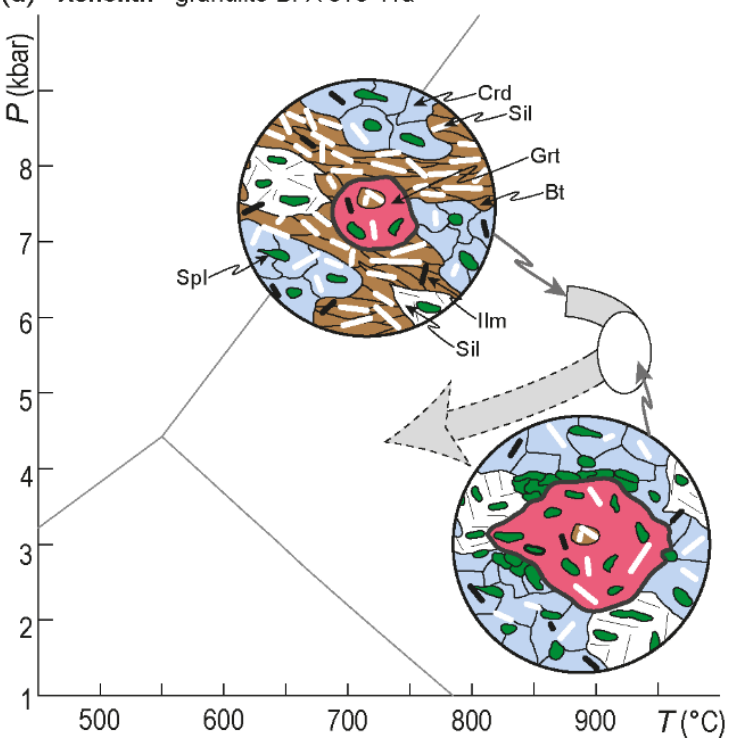

Fig. 7 Sketches summarizing the inferred $P-T$ path and associated crystallization/deformation relationships for (a) regional metamorphism, (b, c) samples in the contact aureole and (d) metapelitic xenoliths. See text and supplementary material for details 
(a) Deep emplacement of the pluton - Dyking - Static heating
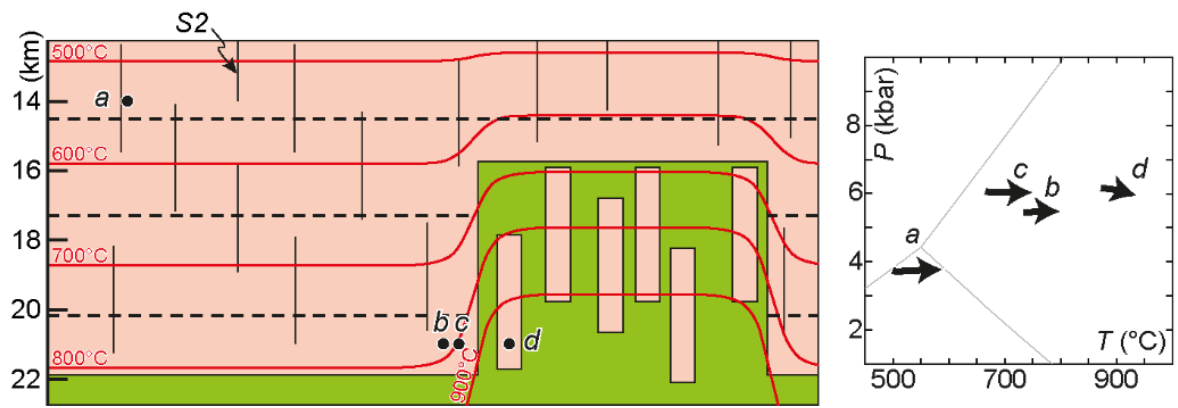

(b) Rise of the pluton - "Diapirism" - D3
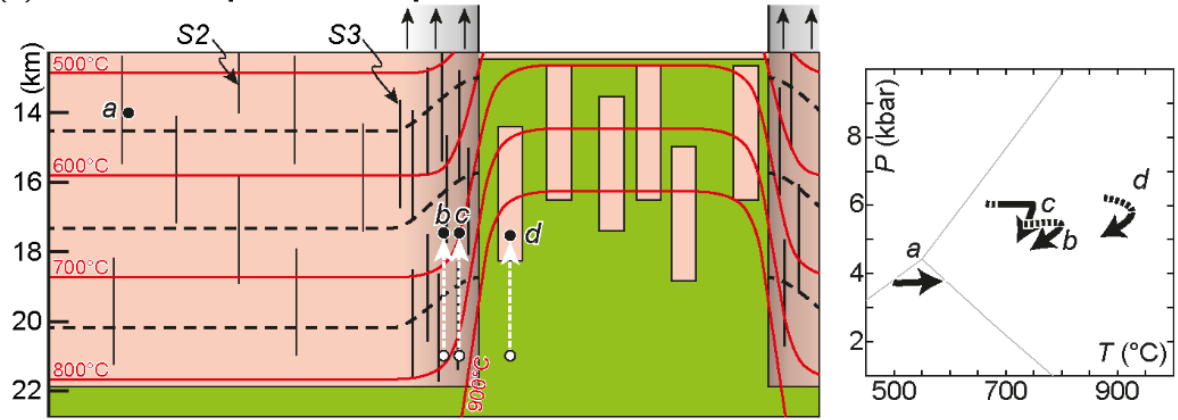

(c) Rise of the pluton and widening of the aureole - "Diapirism" - D3
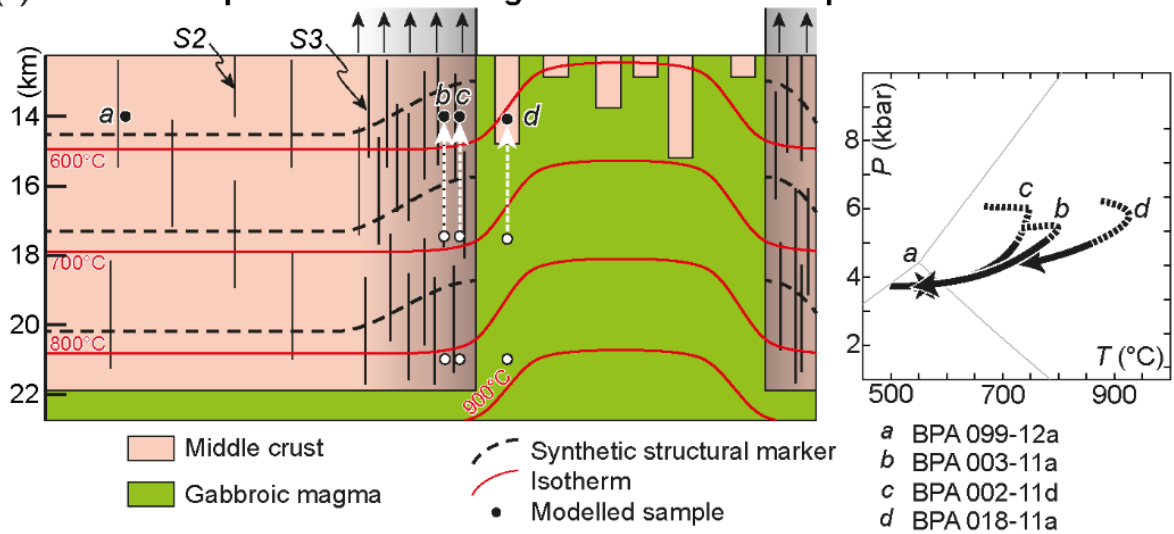

Fig. 8 Model representing a schematic evolution of the area during (a) intrusion of mafic magmas in deep levels; (b) rise of the Sondalo gabbro during shearing in the contact aureole and synchronous exhumation of rocks in the contact aureole; (c) widening of the contact aureole during continuous rise of the Sondalo gabbro 


\section{ELECTRONIC SUPPLEMENTARY MATERIAL}

ESM 1 Field photographs of macroscopic structures and mineralogical relationships

ESM 2 Crystallization-deformation relationships

ESM 3 Representative mineral analyses from samples BPA 099-12a (micaschist from regional metamorphism) and BPA003-11a (Grt-Sil-Bt melanosome from the contact aureole)

ESM 4 Representative mineral analyses from samples BPA 002-11d (Grt-Sil-Bt melanosome from the contact aureole) and BPA 018-11a (granulitic xenolith)

ESM 5 Major element concentration of samples (in wt. \%) obtained from whole rock analyses by ICP-AES and used for mineral equilibria modelling

ESM 6 Petrography, mineral chemistry and mineral equilibria modelling for GrtSil-Bt melanosome BPA 002-11d from the contact aureole

ESM 7 Garnet compositional profiles and maps, and $P-T$ pseudosection for GrtSil-Bt melanosome sample BPA 002-11d from the contact aureole

\section{COMPLIANCE WITH ETHICAL STANDARDS}

Funding: Field work and analyses have been financed by an ExxonMobil research grant to G. Manatschal.

Conflict of Interest: The authors declare that they have no conflict of interest.

\section{REFERENCES}

Ague JJ, Baxter EF (2007) Brief thermal pulses during mountain building recorded by Sr diffusion in apatite and multicomponent diffusion in garnet. Earth Planet Sci Lett 261:500-516. doi: http://dx.doi.org/10.1016/j.eps1.2007.07.017

Aguilar C, Liesa M, Štípská P, Schulmann K, Muñoz JA, Casas JM (2015) P-T-t-d evolution of orogenic middle crust of the Roc de Frausa Massif (Eastern Pyrenees): a result of horizontal crustal flow and Carboniferous doming? J Metamorph Geol 33:273-294.

Annen C (2011) Implications of incremental emplacement of magma bodies for magma differentiation, thermal aureole dimensions and plutonism-volcanism relationships. Tectonophysics 500:3-10. doi: http://dx.doi.org/10.1016/j.tecto.2009.04.010

Annen C, Blundy JD, Sparks RSJ (2006) The Genesis of Intermediate and Silicic Magmas in Deep Crustal Hot Zones. J Petrol 47:505-539. doi:

10.1093/petrology/egi084

Arzi AA (1978) Critical phenomena in the rheology of partially melted rocks. Tectonophysics 44:173-184. doi: http://dx.doi.org/10.1016/0040-1951(78)90069-0

Ashworth JR (1975) Staurolite at anomalously high grade. Contrib Mineral Petrol 53:281-291. doi: 10.1007/bf00382444 
Bachmann G, Grauert B (1981) Radiometrische Alterbestimmungen des Gabbro von Sondalo. Oberes Velltlin, Italienische Alpen. Fortschr Mineral 59:11-13.

Barton MD, Staude J-M, Snow EA, Johnson DA (1991) Aureole systematics. Rev Mineral Geochem 26:723-847.

Bergomi MA, Boriani A (2012) Late Neoproterozoic - Early Paleozoic accretion of the Southalpine and Austroalpine basements of Central Alps (Italy). Géologie de la France 1:69.

Bianchi Potenza B, Carimati R, Potenza R, Testa B (1985) Considerazioni cronologiche sul filone trachitico di Sondalo (Lombardia, Valtellina). Atti Soc Ital Sci Nat Mus Civ Stor Nat Milano 120:141-144.

Bianchi Potenza B, Gorla L, Notarpietro A (1978) La "formazione di Valle Grosina": revisione dei suoi aspetti petrografici in un nuovo contesto geologico II. Gli "gneiss minuti." Rend Soc Ital Mineral Petrol 34:371-385.

Boriani A, Traversi G, Del Moro A, Notarpietro A (1982) Il "granito di Brusio" (Val Poschiavo - Svizzera): caratterizzazioni chimiche, petrologiche e radiometriche. Rend Soc Ital Mineral Petrol 38:97-108.

Bousquet R, Oberhänsli R, Schmid SM, et al. (2012) Metamorphic framework of the Alps.

Braga R, Callegari A, Messiga B, Ottolini L, Renna MR, Tribuzio R (2003) Origin of prismatine from the Sondalo granulites (Central Alps, northern Italy). Eur J Mineral 15:393-400.

Braga R, Giacomini F, Messiga B, Tribuzio R (2001) The Sondalo Gabbroic Complex (Central Alps, Northern Italy): Evidence for Emplacement of Mantle-Derived Melts into Amphibolite Facies Metapelites. Phys Chem Earth Pt A 26:333-342.

Braga R, Massonne H-J, Morten L (2007) An early metamorphic stage for the Variscan Ulten Zone gneiss (NE Italy): evidence from mineral inclusions in kyanite. Mineral Mag 71:691-702. doi: 10.1180/minmag.2007.071.6.691

Brugger J (1994) Les veines à andalousite du Pischahorn (Grisons, Suisse). Schweiz Miner Petrogr Mitt 74:191-202.

Büchi H (1987) Geologie und Petrographie der Bernina IX. Das Gebiet zwischen Pontresina und dem Morteratschgletscher. Unpubl. Diplomarbeit, Univ. Zürich

Büchi H (1994) Der variskiscke Magmatismus in der östlichen Bernina. Schweiz Miner Petrogr Mitt 74:359-371.

Caddick MJ, Konopásek J, Thompson AB (2010) Preservation of Garnet Growth Zoning and the Duration of Prograde Metamorphism. J Petrol 51 :2327-2347.

Campa G, Giacomini F, Giglia A (1997) Carta Geologica del versante sinistro della Valtellina tra la Val di Scala e la Valle delle Presure (Sondrio), Scala 1:10.000. University of Pavia, unpublished master thesis

Clark C, Fitzsimons ICW, Healy D, Harley SL (2011) How Does the Continental Crust Get Really Hot? Elements 7:235-240. doi: 10.2113/gselements.7.4.235 
Clemens JD, Mawer CK (1992) Granitic magma transport by fracture propagation. Tectonophysics 204:339-360. doi: http://dx.doi.org/10.1016/0040-1951(92)90316-X

Coggon R, Holland TJB (2002) Mixing properties of phengitic micas and revised garnetphengite thermobarometers. J Metamorph Geol 20:683-696. doi: 10.1046/j.15251314.2002.00395.x

Costa S, Rey P (1995) Lower crustal rejuvenation and growth during post-thickening collapse: Insights from a crustal cross section through a Variscan metamorphic core complex. Geology 23:905-908. doi: 10.1130/00917613(1995)023<0905:Icragd > 2.3.co;2

Del Moro A, Notarpietro A (1987) Rb-Sr Geochemistry of some Hercynian granitoids overprinted by eo-Alpine metamorphism in the Upper Valtellina, Central Alps. Schweiz Miner Petrogr Mitt 67:295-306.

Dorfler KM, Caddick MJ, Tracy RJ (2015) Thermodynamic Modeling of Crustal Melting Using Xenolith Analogs from the Cortlandt Complex, New York, USA. J Petrol 56 :389-408.

Festa V, Caggianelli A, Langone A, Prosser G (2013) Time-space relationships among structural and metamorphic aureoles related to granite emplacement: a case study from the Serre Massif (southern Italy). Geol Mag 150:441-454.

Floess D, Baumgartner LP (2015) Constraining magmatic fluxes through thermal modelling of contact metamorphism. Geol Soc London Spec Publ 422:41-56.

Florence FP, Spear FS (1991) Effects of diffusional modification of garnet growth zoning on P-T path calculations. Contrib Mineral Petrol 107:487-500. doi: 10.1007/BF00310683

Galli A, Le Bayon B, Schmidt MW, Burg JP, Reusser E, Sergeev SA, Larionov A (2012) $\mathrm{U}-\mathrm{Pb}$ zircon dating of the Gruf Complex: disclosing the late Variscan granulitic lower crust of Europe stranded in the Central Alps. Contrib Mineral Petrol 163:353378. doi: 10.1007/s00410-011-0676-6

Ganguly J (1972) Staurolite Stability and Related Parageneses: Theory, Experiments, and Applications. J Petrol 13:335-365. doi: 10.1093/petrology/13.2.335

García-Casco A, Haissen F, Castro A, El-Hmidi H, Torres-Roldán RL, Millán G (2003) Synthesis of staurolite in melting experiments of a natural metapelite: consequences for the phase relations in low-temperature pelitic migmatites. J Petrol 44:1727-1757. Gazzola D, Gosso G, Pulcrano E, Spalla MI (2000) Eo-Alpine HP metamorphism in the Permian intrusives from the steep belt of the central Alps (Languard-Campo nappe and Tonale Series). Geodin Acta 13:149-167.

Glazner AF, Bartley JM (2006) Is stoping a volumetrically significant pluton emplacement process? Geol Soc Am Bull 118:1189-1195.

Grevel K-D, Navrotsky A, Fockenberg T, Majzlan J (2002) The enthalpy of formation and internally consistent thermodynamic data of Mg-staurolite. Am Mineral 87:397404. 
Guiraud M, Powell R, Rebay G (2001) H2O in metamorphism and unexpected behaviour in the preservation of metamorphic mineral assemblages. J Metamorph Geol 19:445-454. doi: 10.1046/j.0263-4929.2001.00320.x

Guntli R, Liniger M (1989) Metamorphose in der Magma-Decke im Bereich Piz da la Margna und Piz Fedoz (Oberengadin). Schweiz Miner Petrogr Mitt 69:289-301.

Halmes C (1991) Petrographische und geochemische Untersuchungen am Err-Kristallin zwischen St. Moritz und dem Val Bever (Engadin, Graubünden). University of Bern, Lizentiarbeit

Hansmann W, Müntener O, Hermann J (2001) U-Pb zircon geochronology of a tholeiitic intrusion and associated migmatites at a continental crust-mantle transition, Val Malenco, Italy. Schweiz Miner Petrogr Mitt 81:239-255.

Hanson GN, El Tahlawi MR, Weber W (1966) K-Ar and Rb-Sr ages of pegmatites in the South Central Alps. Earth Planet Sci Lett 1:407-413.

Harley SL (1989) The origins of granulites: a metamorphic perspective. Geol Mag 126:215-247.

Hasalová P, Štípská P, Powell R, Schulmann K, Janoušek V, Lexa O (2008) Transforming mylonitic metagranite by open-system interactions during melt flow. $\mathrm{J}$ Metamorph Geol 26:55-80. doi: 10.1111/j.1525-1314.2007.00744.x

Hermann J, Müntener O, Günther D (2001) Differentiation of Mafic Magma in a Continental Crust-to-Mantle Transition Zone. J Petrol 42:189-206. doi: 10.1093/petrology/42.1.189

Hermann J, Müntener O, Trommsdorff V, Hansmann W, Piccardo GB (1997) Fossil crust-to-mantle transition, Val Malenco (Italian Alps). J Geophys Res Solid Earth 102:20123-20132. doi: 10.1029/97jb01510

Hoinkes G, Thöni M (1993) Pre-Mesozoic Geology in the Alps. In: Raumer JF, Neubauer F (eds)Springer Berlin Heidelberg, Berlin Heidelberg, pp 485-494

Holland T, Powell R (2003) Activity-composition relations for phases in petrological calculations: an asymmetric multicomponent formulation. Contrib Mineral Petrol 145:492-501. doi: 10.1007/s00410-003-0464-z

Holland TJB, Powell R (1998) An internally consistent thermodynamic data set for phases of petrological interest. J Metamorph Geol 16:309-343. doi: 10.1111/j.15251314.1998.00140.x

Huppert HE, Sparks RSJ (1988) The generation of granitic magmas by intrusion of basalt into continental crust. J Petrol 29:599-624.

Indares A, White RW, Powell R (2008) Phase equilibria modelling of kyanite-bearing anatectic paragneisses from the central Grenville Province. J Metamorph Geol 26:815-836. doi: 10.1111/j.1525-1314.2008.00788.x

Johnson TE, Brown M, White RW (2010) Petrogenetic modelling of strongly residual metapelitic xenoliths within the southern Platreef, Bushveld Complex, South Africa. J Metamorph Geol 28:269-291. 
Johnson TE, White RW, Brown M (2011) A year in the life of an aluminous metapelite xenolith-The role of heating rates, reaction overstep, $\mathrm{H} 2 \mathrm{O}$ retention and melt loss. Lithos 124:132-143. doi: http://dx.doi.org/10.1016/j.lithos.2010.08.009

Koenig MA (1964) Geologisch-petrographische Untersuchungen im oberen Veltlin. PhD thesis, Universität Zurich

Kriegsman LM, Hensen BJ (1998) Back reaction between restite and melt: Implications for geothermobarometry and pressure-temperature paths. Geology 26:1111-1114. doi: 10.1130/0091-7613(1998)026<1111:brbram>2.3.co;2

Langone A, Braga R, Massonne H-J, Tiepolo M (2011) Preservation of old (prograde metamorphic) $\mathrm{U}-\mathrm{Th}-\mathrm{Pb}$ ages in unshielded monazite from the high-pressure paragneisses of the Variscan Ulten Zone (Italy). Lithos 127:68-85. doi: http://dx.doi.org/10.1016/j.lithos.2011.08.007

Lister JR, Kerr RC (1991) Fluid-mechanical models of crack propagation and their application to magma transport in dykes. J Geophys Res Solid Earth 96:1004910077.

Mahar EM, Baker JM, Powell R, Holland TJB, Howell N (1997) The effect of Mn on mineral stability in metapelites. J Metamorph Geol 15:223-238. doi: 10.1111/j.1525-1314.1997.00011.x

Mancktelow NS (2008) Tectonic pressure: Theoretical concepts and modelled examples. Lithos 103:149-177. doi: http://dx.doi.org/10.1016/j.lithos.2007.09.013

Manzotti P, Rubatto D, Darling J, Zucali M, Cenki-Tok B, Engi M (2012) From PermoTriassic lithospheric thinning to Jurassic rifting at the Adriatic margin: Petrological and geochronological record in Valtournenche (Western Italian Alps). Lithos 146147:276-292. doi: http://dx.doi.org/10.1016/j.lithos.2012.05.007

Markl G (2005) Mullite-corundum-spinel-cordierite-plagioclase xenoliths in the Skaergaard Marginal Border Group: multi-stage interaction between metasediments and basaltic magma. Contrib Mineral Petrol 149:196-215.

Meier A (2003) The Periadriatic Fault System in Valtellina (N-Italy) and the Evolution of the Southwestern Segment of the Eastern Alps. PhD Thesis, ETH Zurich

Mitchell RK, Indares A, Ryan B (2014) High to ultrahigh temperature contact metamorphism and dry partial melting of the Tasiuyak paragneiss, Northern Labrador. J Metamorph Geol 32:535-555.

Mohn G, Manatschal G, Beltrando M, Masini E, Kusznir N (2012) Necking of continental crust in magma-poor rifted margins: Evidence from the fossil Alpine Tethys margins. Tectonics 31:1-28.

Mohn G, Manatschal G, Masini E, Müntener O (2011) Rift-related inheritance in orogens: a case study from the Austroalpine nappes in Central Alps (SE-Switzerland and N-Italy). Int J Earth Sci 100:937-961. doi: 10.1007/s00531-010-0630-2

Müntener O, Hermann J, Trommsdorff V (2000) Cooling History and Exhumation of Lower-Crustal Granulite and Upper Mantle (Malenco, Eastern Central Alps). J 
Petrol 41:175-200. doi: 10.1093/petrology/41.2.175

Pace F (1966) Studio petrografico dell'alta Val Viola (Sondrio). Atti Soc Ital Sci Nat Mus Civ Stor Nat Milano 105:43-60.

Paterson SR, Farris DW (2006) Downward host rock transport and the formation of rim monoclines during the emplacement of Cordilleran batholiths. Earth Environ Sci Trans R Soc Edinb 97:397-413.

Paterson SR, Miller RB (1998) Mid-crustal magmatic sheets in the Cascades Mountains, Washington: implications for magma ascent. J Struct Geol 20:1345-1363.

Paterson SR, Vernon RH (1995) Bursting the bubble of ballooning plutons: A return to nested diapirds emplaced by multiple processes. Geol Soc Am Bull 107:1356-1380.

Paterson SR, Vernon RH, Fowler TK (1991) Aureole tectonics. Rev Mineral Geochem 26:673-722.

Pattison DRM, Tracy RJ (1991) Phase equilibria and thermobarometry of metapelites. Rev Mineral Geochem 26:105-206.

Petri B, Skrzypek E (2013) TCWizard Matlab Package - Help File, 26/04/2013 Update. Online report, University of Strasbourg. Available at: http://eost.unistra.fr/fileadmin/upload/EOST/Benoit_Petri/software1/TCWizard_Hel pFile.pdf.

Powell R, Guiraud M, White RW (2005) Truth and beauty in metamorphic phaseequilibria: conjugate variables and phase diagrams. Can Mineral 43:21-33. doi: 10.2113/gscanmin.43.1.21

Powell R, Holland T, Worley B (1998) Calculating phase diagrams involving solid solutions via non-linear equations, with examples using THERMOCALC. J Metamorph Geol 16:577-588. doi: 10.1111/j.1525-1314.1998.00157.x

Ramberg H (1981) Gravity, deformation and the earth's crust, in theory, experiments and geological application. Academic Press, London

Ring U, Brandon MT, Willett SD, Lister GS (1999) Exhumation processes. Geol Soc London Spec Publ $154: 1-27$.

Rubenach MJ, Bell TH (1988) Microstructural controls and the role of graphite in matrix/ porphyroblast exchange during synkinematic andalusite growth in a granitoid aureole. J Metamorph Geol 6:651-666. doi: 10.1111/j.1525-1314.1988.tb00446.x

Rudnick RL, Fountain DM (1995) Nature and composition of the continental crust: a lower crustal perspective. Rev Geophys 33:267-309.

Sato K, Santosh M, Tsunogae T (2010) High P-T phase relation of magnesian ( $\mathrm{Mg} 0.7 \mathrm{Fe} 0.3$ ) staurolite compositon in the system $\mathrm{FeO}-\mathrm{MgO}-\mathrm{Al} 2 \mathrm{O} 3-\mathrm{SiO} 2-\mathrm{H} 2 \mathrm{O}$ : Implications for prograde high-pressure history of ultrahigh-temperature metamorphic rocks. Am Mineral 95:177-184. doi: 10.2138/am.2010.3170

Schmid SM, Haas R (1989) Transition from near-surface thrusting to Intrabasement Decollement, Schlinig Thrust, eastern Alps. Tectonics 8:697-718. doi: 10.1029/TC008i004p00697 
Schuster R, Stüwe K (2008) Permian metamorphic event in the Alps. Geology 36:603606.

Siivola J, Schmid R (2007) List of Mineral abbreviations - Recommendations by the IUGS Subcomission on the Systematics of Metamorphic Rocks. IUGS web version $0102071-14$.

Sinigoi S, Quick JE, Demarchi G, Klötzli U (2011) The role of crustal fertility in the generation of large silicic magmatic systems triggered by intrusion of mantle magma in the deep crust. Contrib Mineral Petrol 162:691-707. doi: 10.1007/s00410-0110619-2

Skrzypek E, Štípská P, Schulmann K, Lexa O, Lexová M (2011) Prograde and retrograde metamorphic fabrics - a key for understanding burial and exhumation in orogens (Bohemian Massif). J Metamorph Geol 29:451-472. doi: 10.1111/j.15251314.2010.00924.x

Sölva H, Thöni M, Habler G (2003) Dating a single garnet crystal with very high Sm/Nd ratios (Campo basement unit, Eastern Alps). Eur J Mineral 15:35-42.

Spear FS, Kohn MJ, Florence FP, Menard T (1990) A model for garnet and plagioclase growth in pelitic schists: implications for thermobarometry and P-T path determinations. J Metamorph Geol 8:683-696. doi: 10.1111/j.15251314.1990.tb00495.x

Spillmann P, Büchi HJ (1993) The Pre-Alpine Basement of the Lower Austro-Alpine Nappes in the Bernina Massif (Grisons, Switzerland; Valtellina, Italy). In: von Raumer JF, Neubauer F (eds) Pre-Mesozoic Geol. Alps. Springer Berlin Heidelberg, pp 457-467

Štípská P, Powell R (2005) Does ternary feldspar constrain the metamorphic conditions of high-grade meta-igneous rocks? Evidence from orthopyroxene granulites, Bohemian Massif. J Metamorph Geol 23:627-647. doi: 10.1111/j.15251314.2005.00600.x

Thöni M (1981) Degree and evolution of the alpine metamorphism in the Austroalpine unit $\mathrm{W}$ of the Hohe Tauern in the light of $\mathrm{K} / \mathrm{Ar}$ and $\mathrm{Rb} / \mathrm{Sr}$ age determination on micas. Jahrb der Geol Bundesanstalt 124:111-174.

Tribuzio R, Thirlwall MF, Messiga B (1999) Petrology, mineral and isotope geochemistry of the Sondalo gabbroic complex (Central Alps, Northern Italy): implications for the origin of post-Variscan magmatism. Contrib Mineral Petrol 136:48-62. doi: 10.1007/s004100050523

Trümpy R (1975) Penninic-Austroalpine boundary in the Swiss Alps: a presumed former continental margin and its problems. Am J Sci 279:209-238.

Von Quadt A, Grünenfelder M, Büchi H (1994) U-Pb zircon ages from igneous rocks of the Bernina nappe system (Grisons, Switzerland). Schweiz Miner Petrogr Mitt 74:373-382.

Voshage H, Hofmann AW, Mazzucchelli M, Rivalenti G, Sinigoi S, Raczek I, Demarchi 
G (1990) Isotopic evidence from the Ivrea Zone for a hybrid lower crust formed by magmatic underplating. Nature 347:731-736.

Warren RG, Ellis DJ (1996) Mantle underplating, granite tectonics, and metamorphic PT-t paths. Geology 24:663-666. doi: 10.1130/00917613(1996)024<0663:mugtam>2.3.co;2

Waters DJ (2001) The significance of prograde and retrograde quartz-bearing intergrowth microstructures in partially melted granulite-facies rocks. Lithos 56:97-110. doi: http://dx.doi.org/10.1016/S0024-4937(00)00061-X

Wells PRA (1980) Thermal models for the magmatic accretion and subsequent metamorphism of continental crust. Earth Planet Sci Lett 46:253-265.

White RW, Pomroy NE, Powell R (2005) An in situ metatexite-diatexite transition in upper amphibolite facies rocks from Broken Hill, Australia. J Metamorph Geol 23:579-602. doi: 10.1111/j.1525-1314.2005.00597.x

White RW, Powell R (2002) Melt loss and the preservation of granulite facies mineral assemblages. J Metamorph Geol 20:621-632. doi: 10.1046/j.15251314.2002.00206_20_7.x

White RW, Powell R, Clarke GL (2002) The interpretation of reaction textures in Fe-rich metapelitic granulites of the Musgrave Block, central Australia: constraints from mineral equilibria calculations in the system $\mathrm{K} 2 \mathrm{O}-\mathrm{FeO}-\mathrm{MgO}-\mathrm{A} 12 \mathrm{O} 3-\mathrm{SiO} 2-\mathrm{H} 2 \mathrm{O}-$ TiO2-Fe2O3. J Metamorph Geol 20:41-55.

White RW, Powell R, Holland TJB (2007) Progress relating to calculation of partial melting equilibria for metapelites. J Metamorph Geol 25:511-527. doi: 10.1111/j.1525-1314.2007.00711.x

White RW, Powell R, Holland TJB (2001) Calculation of partial melting equilibria in the system Na2O-CaO-K2O-FeO-MgO-Al2O3-SiO2-H2O (NCKFMASH). J Metamorph Geol 19:139-153. doi: 10.1046/j.0263-4929.2000.00303.x

White RW, Powell R, Holland TJB, Johnson TE, Green ECR (2014) New mineral activity-composition relations for thermodynamic calculations in metapelitic systems. J Metamorph Geol 32:261-286. doi: 10.1111/jmg.12071

Wilson M, Neumann E-R, Davies GR, Timmerman MJ, Heeremans M, Larsen BT (2004) Permo-Carboniferous magmatism and rifting in Europe: introduction. Geol Soc London Spec Publ 223:1-10. doi: 10.1144/gsl.sp.2004.223.01.01

Zwart HJ (1962) On the determination of the polymetamorphic mineral associations, and its application to the bosost area (central Pyrenees). Geol Rundsch 52:38-65. 